\title{
Characterization of particulate organic matter in the Lena River delta and adjacent nearshore zone, NE Siberia - Part 2: Lignin-derived phenol compositions
}

\author{
M. Winterfeld ${ }^{1,2}$, M. A. Goñi ${ }^{3}$, J. Just ${ }^{4, *}$, J. Hefter $^{1}$, and G. Mollenhauer ${ }^{1,2}$ \\ ${ }^{1}$ Alfred-Wegener-Institut Helmholtz-Zentrum für Polar- und Meeresforschung, Am Handelshafen 12, \\ 27570 Bremerhaven, Germany \\ ${ }^{2}$ Department of Geosciences, University of Bremen, Klagenfurter Straße, 28359 Bremen, Germany \\ ${ }^{3}$ College of Earth, Ocean and Atmospheric Sciences, Oregon State University, Corvallis, OR 97331, USA \\ ${ }^{4}$ MARUM, Center for Marine Environmental Sciences and Department of Geosciences, University of Bremen, \\ Klagenfurter Straße, 28359 Bremen, Germany \\ *now at: Institute of Geology and Mineralogy, University of Cologne, Zülpicher Str. 49a, 50674 Cologne, Germany
}

Correspondence to: M. Winterfeld (maria.winterfeld@awi.de)

Received: 9 August 2014 - Published in Biogeosciences Discuss.: 8 October 2014

Revised: 17 February 2015 - Accepted: 2 March 2015 - Published: 15 April 2015

\begin{abstract}
The Lena River in central Siberia is one of the major pathways translocating terrestrial organic matter (OM) from its vast catchment area to the coastal zone of the Laptev Sea and the Arctic Ocean. The permafrost soils of its far south-stretching catchment, which store huge amounts of OM, will most likely respond differently to climate warming and remobilize previously frozen OM with distinct properties specific for the source vegetation and soil. To characterize the material discharged by the Lena River, we analyzed the lignin phenol composition in total suspended matter (TSM) from surface water collected in spring and summer, surface sediments from Buor Khaya Bay along with soils from the Lena Delta's first (Holocene) and third terraces (Pleistocene ice complex), and plant samples. Our results show that lignin-derived cinnamyl : vanillyl $(\mathrm{C} / \mathrm{V})$ and syringyl : vanillyl $(\mathrm{S} / \mathrm{V})$ ratios are $>0.14$ and 0.25 , respectively, in TSM and surface sediments, whereas in delta soils they are $>0.16$ and $>0.51$, respectively. These lignin compositions are consistent with significant inputs of organic matter from non-woody angiosperm sources mixed with organic matter derived from woody gymnosperm sources. We applied a simple linear mixing model based on the $\mathrm{C} / \mathrm{V}$ and $\mathrm{S} / \mathrm{V}$ ratios, and the results indicate the organic matter in delta TSM samples and Buor Khaya Bay surface sediments contain comparable contributions from gymnosperm mate-
\end{abstract}

rial, which is primarily derived from the taiga forests south of the delta, and angiosperm material typical for tundra vegetation. Considering the small catchment area covered by tundra $(\sim 12 \%)$, the input is substantial and tundra-derived OM input is likely to increase in a warming Arctic. The similar and high acid to aldehyde ratios of vanillyl and syringyl $\left(\mathrm{Ad} / \mathrm{Al}_{\mathrm{V}, \mathrm{S}}\right)$ in Lena Delta summer TSM $(>0.7$ and $>0.5$, respectively) and Buor Khaya Bay surface sediments (> 1.0 and $>0.9$, respectively) suggest that the OM is highly degraded and Lena River summer TSM could be a possible source of the surface sediments. The Ad / $\mathrm{Al} V$, s ratios of the first and third delta terraces were generally lower (mean ratios $>0.4$ and $>0.4$, respectively) than summer TSM and surface sediments. This implies that TSM contains additional contributions from a more degraded OM source (southern catchment and/or finer more degraded particle size). Alternatively, OM degradation on land after permafrost thawing and subaqueously during transport and sedimentation could be considerable. Despite the high natural heterogeneity of OM stored in delta soils and exported by the Lena River, the catchment-characteristic vegetation is reflected by the lignin biomarker composition. Climate-warming-related changes in the Lena River catchment may be detectable in changing lignin biomarker composition and diagenetic alteration. 


\section{Introduction}

Within the permafrost-affected soils of the high northern latitudes lies a huge organic carbon (OC) reservoir, estimated to be as big as $1400-1850 \mathrm{Pg}$ carbon, representing about $50 \%$ of the global soil OC (Tarnocai et al., 2009). Currently most of this OC pool remains frozen and is therefore excluded from biogeochemical cycles. Over the last decades mean annual air temperatures in the Arctic have increased more strongly than the global mean, and this trend is projected to continue (IPCC, 2013). As a result, annual permafrost thaw depths and Arctic river runoff have increased (McClelland et al., 2012; Peterson et al., 2002), likely leading to enhanced mobilization and export of old, previously frozen soil-derived OC (e.g., Guo et al., 2004; Schuur et al., 2008; Vonk et al., 2010). Consequently, the great Arctic rivers play an important role in global biogeochemical cycles by connecting the large permafrost carbon pool of their hinterlands with the Arctic shelf seas and the Arctic Ocean.

Terrigenous sediments reaching the nearshore zone and shelves serve as archives recording changes in material derived from river catchments and from erosion of permafrost coasts. The particulate organic matter associated with these sediments consists of a complex mixture of compounds from different aquatic and terrigenous sources with different chemical/physical recalcitrance towards decomposition and mineralization. Determining the sources (e.g., phytoplankton, vegetation, surface soil, mineral-associated soil, peat) and quality of $\mathrm{OC}$ transported by Arctic rivers is therefore important to understand the effects of climate change on the river watersheds as well as on the Arctic coastal zone.

Recent studies using molecular organic compounds and their carbon isotopes have shown that there are great differences in the age, quality, and source of OM exported by individual rivers (Dickens et al., 2011; Drenzek et al., 2007; Feng et al., 2013; Goñi et al., 2013, 2000; Gustafsson et al., 2011; Karlsson et al., 2011; Kuzyk et al., 2008; Unger et al., 2005; Vonk et al., 2010). The catchments of the great Arctic rivers in North America and Siberia cover several climate zones. Their response to climate change will most likely vary strongly between the temperate and high-latitude regions, affecting river biogeochemical carbon cycling in different ways. Knowing where the OM derives from (southern vs. northern part of the catchment), as well as if and how the relative contributions of climatic zones to riverine POC may change with climate warming, is important for understanding and evaluating different permafrost thawing scenarios and their projected effect on the global climate.

Research efforts on studying Arctic rivers has increased in the last decades, and the spatial and temporal data resolution on dissolved and particulate organic matter has improved. Nonetheless, the resolution is still relatively low, especially for riverine POC. The main reasons for this are the great logistical difficulties of conducting fieldwork in these remote
Arctic regions under mainly severe climate conditions, especially for winter and spring campaigns.

This is the second of two papers (see same issue) dealing with particulate organic matter from the Lena River delta and adjacent Buor Khaya Bay. The Lena River is one of the biggest Siberian rivers in terms of water and sediment discharge and an important source of sediment as well as dissolved and particulate organic matter to the Laptev Sea and Arctic Ocean (Holmes et al., 2002, 2012; Rachold, 1999). In recent years, several studies have investigated the input, composition, and transport mechanisms of sediments delivered by the Lena River and by erosion of permafrost coasts (e.g., Charkin et al., 2011; Günther et al., 2013; Karlsson et al., 2011; Rachold and Hubberten, 1999; Semiletov et al., 2011). However, it is still under debate as to how OM from the two main sources (riverine vs. coastal erosion) affects the total carbon budget and cycling in the Laptev Sea. Our samples were taken during field campaigns in the summers of 2009 and 2010 as well as in spring 2011. Here, we present new data on particulate OC composition and quality from riverbank soil profiles of the eastern Holocene first delta terrace and the Pleistocene third terrace of Kurungnakh Island (e.g., Schwamborn et al., 2002), surface water particulate matter along the main delta channels, and surface sediments from Buor Khaya Bay. We used the lignin phenol composition to distinguish the sources of OM transported by the river, namely the taiga forest in the southern catchment versus the tundra covering the northernmost part of the watershed including the delta. The alkaline cupric oxide $(\mathrm{CuO})$ oxidation products are also used to characterize the degree of aerobic degradation of lignin in these samples.

Lignin is a biopolymer produced almost exclusively by terrestrial vascular plants. Through $\mathrm{CuO}$ oxidation it is possible to break up the polymer structure and analyze the main building blocks, the lignin-derived phenols, and other $\mathrm{CuO}$ oxidation products by gas chromatography-mass spectrometry (GC-MS). This method has been successfully applied in numerous studies to a variety of environments including the Arctic to trace soil-derived OM and differentiate between gymnosperm and angiosperm plants as well as between woody and non-woody tissues as sources (see Bianchi et al., 2007; Goñi et al., 2000; Hedges and Mann, 1979; Kuzyk et al., 2008; Onstad et al., 2000; Opsahl et al., 1999; Prahl et al., 1994; Tesi et al., 2011). Furthermore, lignin is believed to be a rather recalcitrant fraction of soil organic matter, although this model is currently under debate (Feng et al., 2008).

Considering that, our study in the Lena Delta can serve as possible benchmark against which future changes in $\mathrm{OM}$ composition and quality associated with a warming Siberian Arctic could be assessed. Because of our sampling location in the delta covered by tundra vegetation, we provide lignin compositional information from the Lena River including the whole catchment and compare these results with data from more southern Lena River sampling locations (e.g., Amon et 
al., 2012). Further, characterizing the riverine particulate organic matter can improve our understanding of organic matter delivery cycling in the near-coastal zone of Buor Khaya Bay and the Laptev Sea.

\section{Material and methods}

\subsection{Study area}

The Lena River is one of the largest Russian Arctic rivers, draining an area of $\sim 2.46 \times 10^{6} \mathrm{~km}^{2}$ in central Siberia (Fig. 1a). Its watershed stretches from $53^{\circ} \mathrm{N}$ near Lake Baikal to $71^{\circ} \mathrm{N}$, where the river discharges into the Laptev Sea and Arctic Ocean. Because of its huge extension, the Lena River basin comprises a diverse flora and fauna. In general, the basin can be divided into two major vegetation zones transitioning from south to north: (1) the boreal forest or taiga, which covers about $72 \%$ of the watershed, and (2) a small tundra zone in the north representing $12 \%$ of the basin area (the remaining area is categorized as water bodies, cropland, etc.; see Amon et al., 2012) consisting mainly of wet and dry dwarf-shrub tundra and sedge/grass wetland tundra (CAVM Team, 2003). About $90 \%$ of the Lena River catchment is characterized by continuous and discontinuous permafrost (72-80 and 6-10\% of basin area, respectively; (Amon et al., 2012; Zhang et al., 2005). The permafrost table beneath the seasonally thawed layer (active layer) acts as water-impermeable layer and thus its distribution has a large impact on regional hydrology and hydrochemistry. Because of the extreme continental climate of central Siberia with average temperatures around $-45^{\circ} \mathrm{C}$ in January and up to $+35^{\circ} \mathrm{C}$ in August, the Lena River water discharge varies strongly throughout the seasons (e.g., Holmes et al., 2012). The river is covered by a thick ice layer $(\sim 2 \mathrm{~m})$ from October to late May/June, and runoff is comparatively low during this time of the year (Yang et al., 2002). It reaches its maximum during the spring ice breakup and snowmelt in late May to June, when more than $50 \%$ of the annual freshwater, sediment, and dissolved and particulate organic matter discharge into the Laptev Sea takes place (Rachold et al., 2004). With a mean annual water discharge of $\sim 588 \mathrm{~km}^{3}$ between 1999 and 2008 (Holmes et al., 2012), the Lena ranks as the second largest of the Russian rivers after the Yenisey. Corresponding annual sediment, dissolved organic carbon (DOC), and particulate organic carbon (POC) fluxes are $20.7 \mathrm{Tg} \mathrm{yr}^{-1}$ (Holmes et al., 2002), 5.7 $\mathrm{Tg} \mathrm{yr}^{-1}$ (Holmes et al., 2012), and $1.2 \mathrm{Tg} \mathrm{yr}^{-1}$ respectively (Rachold and Hubberten, 1999). A second major source of terrestrial organic matter delivered to the Laptev Sea is the sediment input by thermal erosion of the ice-rich Pleistocene ice complex or Yedoma deposits along the coast (see Gustafsson et al., 2011; Mueller-Lupp et al., 2000; Rachold and Hubberten, 1999). Annual supply of sedimentary material and total organic carbon to the Laptev Sea by coastal erosion is estimated to be $\sim 58.4$ and $1.8 \mathrm{Tg} \mathrm{yr}^{-1}$, respectively (Stein and Fahl, 2004).

The Lena River delta is the largest Arctic delta, with an area of $\sim 32000 \mathrm{~km}^{2}$. It can be divided into three geomorphological terraces (Grigoriev, 1993; Schwamborn et al., 2002). The first terrace includes the active floodplains that were formed during the Holocene and makes up about $55 \%$ of the total delta area (Morgenstern et al., 2008) covering the central and eastern part. Within the first delta terrace, remains of a Pleistocene accumulation plain, also called ice complex or Yedoma deposits, form the third terrace, covering about $6 \%$ of the total delta area (Morgenstern et al., 2008). Sandy islands forming the second terrace cover the rest of the delta area in the west. The first and third terraces formed under completely different conditions. Whereas fluvial highenergy depositional regime characterize the Holocene (e.g., Schwamborn et al., 2002), the Pleistocene terraces were formed under a comparatively low-energy alluvial and proluvial depositional regime (e.g., Schirrmeister et al., 2011). These contrasts result in distinct differences in OC content and quality, extent of soil formation, composition of the soil matrix, and ice content. Erosion of exposed surfaces means that both terraces contribute to the suspended particulate matter in the Lena Delta surface water sampled for this study, as well as suspended matter transported by the river from the southern catchment area.

Lena River water and sediment discharge is not equally distributed through the different delta channels (Fig. 1b). Approximately $80-90 \%$ of the total water and up to $85 \%$ of the sediment discharge are delivered through the three main eastern channels to Buor Khaya Bay east of the delta, i.e., through the Sardakhsko-Trofimovskaya channel system (60-75\% water, $70 \%$ sediment) and the Bykovskaya channel (20-25\% water, $15 \%$ sediment). Only a minor portion is discharged to the north and west through the Tumatskaya and Olenyokskaya channels (5-10\% water, $10 \%$ sediment; Ivanov and Piskun, 1999).

All riverbank bluffs sampled here belong to the first terrace, which is elevated ( 5 to $16 \mathrm{~m}$ ) over the active floodplains. The bluff profiles vary strongly in sediment composition and organic matter content. Within the profiles, sandy layers derived from extreme flooding events (Schwamborn et al., 2002) and aeolian input (Kutzbach et al., 2004; Sanders, 2011) alternate with buried surface soil layers and peat layers rich in fibrous plant and root detritus in different stages of decomposition. The peat layers are either of autochthonous or allochthonous origin. Allochthonous material is eroded from river banks further upstream and re-deposited in the delta.

The first terrace is characterized by wet polygonal tundra with depressed polygon centers and elevated polygon rims. Phytologically, the polygon centers are dominated by hydrophilic sedges like Carex aquatilis, Carex chordorrhiza, and Carex rariflora and mosses (e.g., Drepanocladus revolvens, Aulacomnium turgidum), and the rims by mesophilic dwarf shrubs (e.g., Salix glauca) and mosses (e.g., Hylo- 


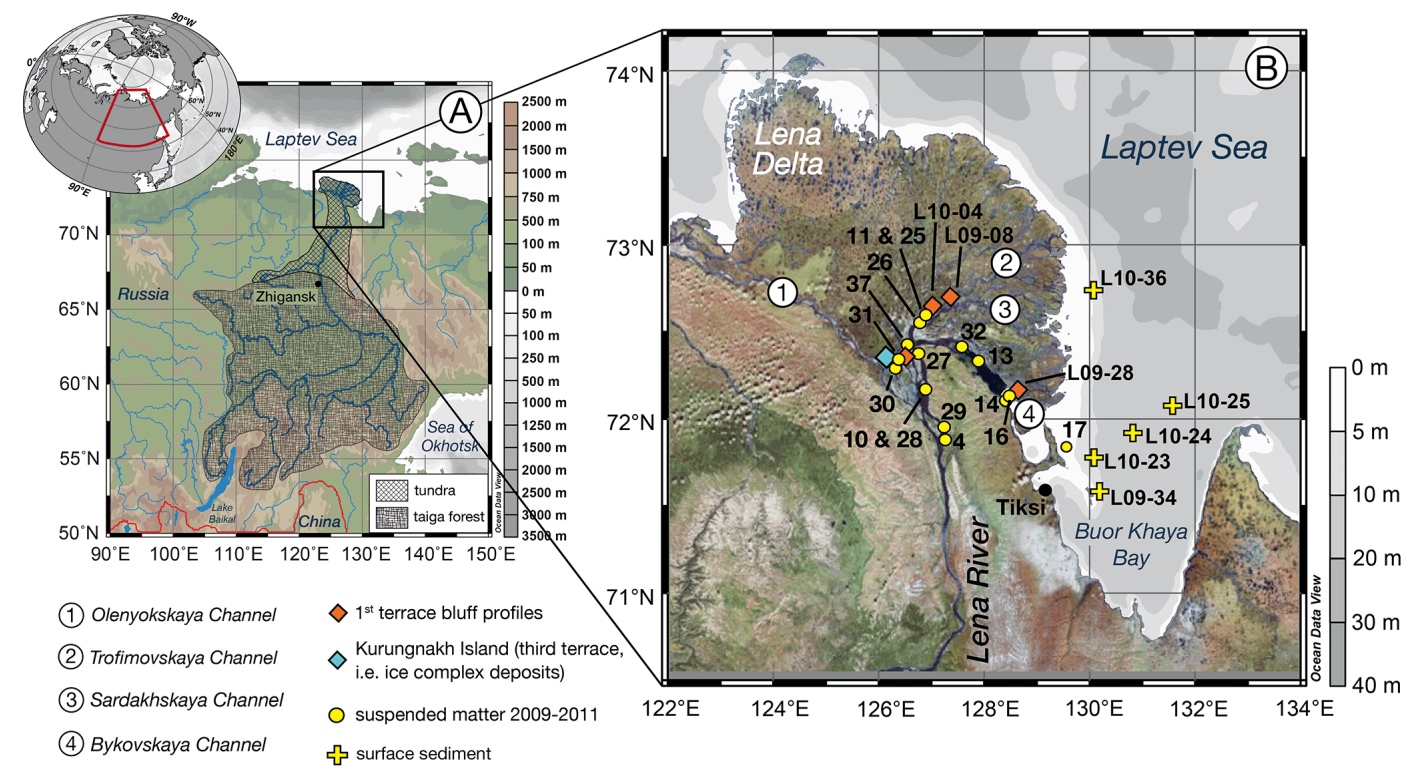

Figure 1. (a) Lena River catchment area with approximate tundra and taiga forest distribution; (b) Lena Delta and Buor Khaya Bay sampling sites from 2009 to 2011 and associated sample codes.

comium splendens, Timmia austriaca; Boike et al., 2013; Kutzbach et al., 2004; Sachs et al., 2010).

\subsection{Sampling}

The sampling sites presented in this study are located in the eastern part of the Lena Delta and adjacent Buor Khaya Bay (Fig. 1b). Permafrost soil samples, total suspended matter (TSM) from surface waters, and surface sediments were collected during two expeditions in August 2009 and July/August 2010. Additional TSM samples were collected during the Lena River freshet in late May 2011. Four Holocene permafrost peat bluffs of different heights $(3$ to $8 \mathrm{~m}$ above river level in August 2009 and July/August 2010) were sampled along the main channels of the first delta terrace (all sampling sites in Fig. 1b and Table 1). In order to obtain samples that reflect the original state of the frozen permafrost soils, thawed material was removed with a spade for the total height of each bluff. Frozen pieces of peat were excavated at different depths using a hatchet and hammer.

Suspended particulate matter of Lena River surface water was sampled at different stations in the main river channels of the delta on the Russian vessel Puteyski 405 (Fig. 1b, Table 1). Between 1 and $30 \mathrm{~L}$ of water was filtered on precombusted $\left(4.5 \mathrm{~h}\right.$ at $\left.450^{\circ} \mathrm{C}\right)$ and pre-weighed glass fiber filters $(\mathrm{GF} / \mathrm{F}$ Whatman, $0.7 \mu \mathrm{m}$ membrane, $\varnothing 142 \mathrm{~mm})$ for biomarker analysis. Additionally, water samples of 15 and $20 \mathrm{~L}$ from the spring freshet in 2011 were stored cooled in opaque canisters for several days to allow for the suspended matter to settle. Before the supernatant water was decanted, it was filtered on pre-combusted and pre-weighed GF/F filters to check for the TSM remaining in suspension. For the sample presented here (sample ID 37), the TSM of the supernatant water represented $0.1 \%$ of the settled material on a dry weight basis and therefore the loss of material in suspension can be neglected.

Surface sediment samples from the Lena riverbed and off Muostakh Island were taken in 2009 using a grab sampler onboard the Puteyski 405. Surface sediments from Buor Khaya Bay were taken in 2010 with the Russian vessel PTS using a steel tube $(\varnothing 5 \mathrm{~cm})$ connected to a rope. Penetration depths into sediment were between 3 and $6 \mathrm{~cm}$.

The peat and sediment samples were stored in precombusted glass jars $\left(4.5 \mathrm{~h}\right.$ at $\left.450^{\circ} \mathrm{C}\right)$, and $\mathrm{GF} / \mathrm{F}$ filters were wrapped in pre-combusted aluminum foil. All samples were kept frozen at $-20^{\circ} \mathrm{C}$ during storage and transport until analysis.

In addition to the samples taken for this study, we analyzed five samples (two from the early Holocene, three from the Pleistocene) from a profile on Kurungnakh Island, which were taken in 2002 and provided by Lutz Schirrmeister from the AWI Potsdam, Germany. A detailed description of the study site and the paleoenvironmental interpretation can be found in Wetterich et al. (2008). Furthermore, vegetation samples collected further south along the Lena River were provided by Ulrike Herzschuh and Juliane Klemm from the AWI Potsdam, Germany (for more information on the sampling sites see Herzschuh et al., 2009; Klemm and Zubrzycki, 2009; Zubrzycki et al., 2012). Plant species analyzed here were Aulacomnium turgidum (moss), Ledum palustre (wild rosemary), Carex spp. (sedges), Betula nana (dwarf birch), Salix (willow), and Larix (larch). 
Table 1. Samples presented in this study and analyzed for lignin phenol composition. Bluff height is given in meters above river level [m a.r.l.] measured in August 2009 and July/August 2010. All total suspended matter samples from 2009 to 2011 were taken from the surface water layer with a sampling depth of ca. $0.5 \mathrm{~m}$. Additional surface water samples used for total suspended matter determination can be found in Table S1 in the Supplement. Not applicable denoted by n/a.

\begin{tabular}{|c|c|c|c|c|c|c|}
\hline Sample code & Sample and site description & Date of sampling & $\begin{array}{r}\text { Latitude N } \\
\text { [deg] }\end{array}$ & $\begin{array}{r}\text { Longitude E } \\
\text { [deg] }\end{array}$ & $\begin{array}{l}\text { Bluff height } \\
\text { [m a.r.1.] }\end{array}$ & $\begin{array}{r}\text { Water depth } \\
{[\mathrm{m}]}\end{array}$ \\
\hline \multicolumn{7}{|c|}{ Lena Delta first terrace bluff profiles } \\
\hline L09-08 & Gorgolevsky Island, 3 depths sampled & 17 Aug 2009 & 72.6158 & 127.2627 & 3.4 & $\mathrm{n} / \mathrm{a}$ \\
\hline L09-12 & Samoylov Island, 5 depths sampled & 18 Aug 2009 & 72.3775 & 126.4954 & 7.5 & $\mathrm{n} / \mathrm{a}$ \\
\hline L09-28-2 & Bykovskaya Channel, 2 depths sampled & 21 Aug 2009 & 72.0586 & 128.6309 & 1.7 & $\mathrm{n} / \mathrm{a}$ \\
\hline L10-04 & Baron Belkey Island, 6 depths sampled & 31 Jul 2010 & 72.5378 & 126.8608 & 6.5 & $\mathrm{n} / \mathrm{a}$ \\
\hline \multicolumn{7}{|c|}{ Kurungnakh Island third terrace ${ }^{\mathrm{a}}$} \\
\hline S29 & Unit $\mathrm{V}$, middle Holocene & Aug 2002 & 72.3447 & 126.3092 & 37.0 & $\mathrm{n} / \mathrm{a}$ \\
\hline S17 & Unit IVb, early Holocene & Aug 2002 & 72.3447 & 126.3092 & 37.0 & $\mathrm{n} / \mathrm{a}$ \\
\hline S13 & Unit IVa, Pleistocene ice complex & Aug 2002 & 72.3447 & 126.3092 & 37.0 & $\mathrm{n} / \mathrm{a}$ \\
\hline S22D & Unit III, Pleistocene ice complex & Aug 2002 & 72.3447 & 126.3092 & 37.0 & $\mathrm{n} / \mathrm{a}$ \\
\hline S45 & Unit III, Pleistocene ice complex & Aug 2002 & 72.3431 & 126.3056 & 37.0 & $\mathrm{n} / \mathrm{a}$ \\
\hline \multicolumn{7}{|c|}{ Lena River total suspended matter } \\
\hline 4 & Lena River main channel south of Tit Ari Island & 16 Aug 2009 & 71.9040 & 127.2544 & $\mathrm{n} / \mathrm{a}$ & $\mathrm{n} / \mathrm{a}$ \\
\hline 10 & Lena River main channel & 19 Aug 2009 & 72.2760 & 126.9041 & $\mathrm{n} / \mathrm{a}$ & $\mathrm{n} / \mathrm{a}$ \\
\hline 11 & Lena River main channel & 19 Aug 2009 & 72.5159 & 126.7142 & $\mathrm{n} / \mathrm{a}$ & $\mathrm{n} / \mathrm{a}$ \\
\hline 13 & Lena River Bykovskaya Channel & 20 Aug 2009 & 72.2352 & 127.9619 & $\mathrm{n} / \mathrm{a}$ & $\mathrm{n} / \mathrm{a}$ \\
\hline 14 & Lena River Bykovskaya Channel & 20 Aug 2009 & 72.0341 & 128.5232 & $\mathrm{n} / \mathrm{a}$ & $\mathrm{n} / \mathrm{a}$ \\
\hline 16 & Lena River Bykovskaya Channel & 21 Aug 2009 & 72.0586 & 128.6309 & $\mathrm{n} / \mathrm{a}$ & $\mathrm{n} / \mathrm{a}$ \\
\hline 17 & Offshore of Bykovsky Peninsula & 22 Aug 2009 & 71.7889 & 129.4189 & $\mathrm{n} / \mathrm{a}$ & $\mathrm{n} / \mathrm{a}$ \\
\hline 25 & Lena River Trofimoskaya Channel & 31 Jul 2010 & 72.4764 & 126.6250 & $\mathrm{n} / \mathrm{a}$ & $\mathrm{n} / \mathrm{a}$ \\
\hline 26 & Lena River Trofimoskaya Channel & $31 \mathrm{Jul} 2010$ & 72.4764 & 126.8588 & $\mathrm{n} / \mathrm{a}$ & $\mathrm{n} / \mathrm{a}$ \\
\hline 27 & Lena River main channel south of Samoylov & 1 Aug 2010 & 72.3776 & 126.7478 & $\mathrm{n} / \mathrm{a}$ & $\mathrm{n} / \mathrm{a}$ \\
\hline 28 & Lena River main channel north of Tit Ari Island & 1 Aug 2010 & 72.2102 & 126.9423 & $\mathrm{n} / \mathrm{a}$ & $\mathrm{n} / \mathrm{a}$ \\
\hline 29 & Lena River main channel south of Tit Ari Island & 1 Aug 2010 & 71.9514 & 127.2582 & $\mathrm{n} / \mathrm{a}$ & $\mathrm{n} / \mathrm{a}$ \\
\hline 30 & Lena River main channel off Kurungnakh & 2 Aug 2010 & 72.2808 & 126.2091 & $\mathrm{n} / \mathrm{a}$ & $\mathrm{n} / \mathrm{a}$ \\
\hline 31 & Lena River main channel & 2 Aug 2010 & 72.3567 & 126.3521 & $\mathrm{n} / \mathrm{a}$ & $\mathrm{n} / \mathrm{a}$ \\
\hline 32 & Lena River Bykovskaya Channel & 3 Aug 2010 & 72.3604 & 127.6761 & $\mathrm{n} / \mathrm{a}$ & $\mathrm{n} / \mathrm{a}$ \\
\hline 37 & Lena River main channel off Samoylov Island & 29 May 2011 & 72.3651 & 126.4757 & $\mathrm{n} / \mathrm{a}$ & $\mathrm{n} / \mathrm{a}$ \\
\hline \multicolumn{7}{|c|}{ Buor Khaya Bay surface sediments } \\
\hline L09-34 & Surface sediment (grab sampler) off Muostakh Island & 23 Aug 2009 & 71.5750 & 129.8200 & $\mathrm{n} / \mathrm{a}$ & 10.5 \\
\hline L10-23 & Surface sediment (steel tube) & 4 Aug 2010 & 71.7778 & 130.0872 & $\mathrm{n} / \mathrm{a}$ & 11.5 \\
\hline L10-24 & Surface sediment (steel tube) & 4 Aug 2010 & 71.9250 & 130.8227 & $\mathrm{n} / \mathrm{a}$ & 17.0 \\
\hline L10-25 & Surface sediment (steel tube) & 4 Aug 2010 & 72.0725 & 131.5896 & $\mathrm{n} / \mathrm{a}$ & 17.0 \\
\hline L10-36 & Surface sediment (steel tube) & 6 Aug 2010 & 72.7411 & 130.1324 & $\mathrm{n} / \mathrm{a}$ & 5.8 \\
\hline \multicolumn{7}{|c|}{ Vegetation samples $^{\mathrm{b}}$} \\
\hline 09-TIK-04 & Aulacomnium turgidum & Jul/Aug 2009 & 72.8087 & 124.9121 & $\mathrm{n} / \mathrm{a}$ & $\mathrm{n} / \mathrm{a}$ \\
\hline 09-TIK-01 & Carex spp. & Jul/Aug 2009 & 73.1731 & 124.5757 & $\mathrm{n} / \mathrm{a}$ & $\mathrm{n} / \mathrm{a}$ \\
\hline 09-TIK-13 & Ledum palustre & Jul/Aug 2009 & 69.3991 & 123.8261 & $\mathrm{n} / \mathrm{a}$ & $\mathrm{n} / \mathrm{a}$ \\
\hline 09-TIK-13 & Betula nana & Jul/Aug 2009 & 69.3991 & 123.8261 & $\mathrm{n} / \mathrm{a}$ & $\mathrm{n} / \mathrm{a}$ \\
\hline 09-TIK-13 & Salix spp. & Jul/Aug 2009 & 69.3991 & 123.8261 & $\mathrm{n} / \mathrm{a}$ & $\mathrm{n} / \mathrm{a}$ \\
\hline 09-TIK-13 & Larix (mostly needles) & Jul/Aug 2009 & 69.3991 & 123.8261 & $\mathrm{n} / \mathrm{a}$ & $\mathrm{n} / \mathrm{a}$ \\
\hline
\end{tabular}

a Samples provided by L. Schirrmeister (Alfred Wegener Institute Potsdam, Germany); data from Wetterich et al. (2008). ${ }^{\text {b }}$ Samples provided by U. Herzschuh (Alfred Wegener Institute Potsdam, Germany); expedition field reports by Herzschuh et al. (2009) and Klemm and Zubrzycki (2009).

\subsection{Laboratory analyses}

Peat and sediment samples were freeze-dried, homogenized, and subsampled for elemental and biomarker analysis.

All filters were oven-dried at $40^{\circ} \mathrm{C}$ for $24 \mathrm{~h}$. Due to expected problems with alkaline $\mathrm{CuO}$ oxidation of glass fiber filters in the microwave (dissolution of glass fiber), the particulate matter from samples selected for $\mathrm{CuO}$ oxidation was carefully scraped off the filter with a scalpel. During the filtering process a large portion of the particulate matter settled within the membrane structure. Therefore it was only possible to scrape off the material sitting directly on the filter 
surface. This material made up between 23 and $72 \%$ (mean: $50 \%$ ) of the total TSM on the filters. Because of this treatment, the measured $\mathrm{CuO}$ oxidation products cannot accurately be related to the original water volume filtered and are rather treated like sediment samples normalized to the sample weight and weight of organic carbon.

\subsubsection{Elemental analyses}

Weight percent organic carbon (OC) and total nitrogen (TN) content of soil and sediment samples were determined by high-temperature combustion after removal of carbonates as described by Goñi et al. (2003). The particulate organic carbon (POC) and particulate nitrogen (PN) content of TSM were analyzed on $\varnothing 25 \mathrm{~mm}$ and $\emptyset 47 \mathrm{~mm}$ GF/F obtained from the same water sample as the respective $\varnothing 142 \mathrm{~mm}$ filters, which were scraped for lignin phenol analysis.

\subsubsection{CuO oxidation products}

Alkaline $\mathrm{CuO}$ oxidation was performed at Oregon State University based on the method described by Goñi and Montgomery (2000). Alkaline oxidations were carried out with nitrogen-purged $2 \mathrm{~N} \mathrm{NaOH}$ at $150^{\circ} \mathrm{C}$ for $1.5 \mathrm{~h}$ using a microwave digestion system. After the oxidation, recovery standards (ethyl vanillin, trans-cinnamic acid) were added and the solution was acidified to $\mathrm{pH} 1$ with concentrated $\mathrm{HCl}$. Subsequently, samples were extracted with ethyl acetate. Extracts were evaporated to dryness under a stream of nitrogen. $\mathrm{CuO}$ reaction products were re-dissolved in pyridine and derivatized with bis-trimethylsilyl trifluoroacetoamide (BSTFA)+1\% trimethylchlorosilane (TCMS) to silylate exchangeable hydrogens prior to analysis by gas chromatography-mass spectrometry (GC-MS). Compounds were separated chromatographically in a $30 \mathrm{~m} \times 250 \mu \mathrm{m}$ DB1 ( $0.25 \mu \mathrm{m}$ film thickness) capillary GC column, using an initial temperature of $100^{\circ} \mathrm{C}$, a temperature ramp $4{ }^{\circ} \mathrm{C} \mathrm{min}-1$ and a final temperature of $300^{\circ} \mathrm{C}$. GC-MS was used to identify and quantify individual biomarkers (e.g., Goñi et al., 2009). The GC-MS was set to scan from 50 to $650 \mathrm{amu}$ and used to acquire full spectra of compounds of interest that were compared to those of standards to confirm identities. Individual compounds were quantified based on the intensities of selected ions using multi-level calibrations run routinely during the analysis period. Yields of non-lignin products were quantified using the detector response of $t$-cinnamic acid. External calibration standards were determined for individual compounds using ions specific to each chemical structure. The calibrations, which were performed on a weekly basis to test the response of the GC-MS, were highly linear $\left(r^{2}>0.99\right)$ over the concentration ranges measured in the samples. A more detailed method description can be found in Goñi et al. (2009) and Hatten et al. (2012).

Quantified reaction products included eight lignin-derived compounds: vanillyl phenols (V: vanillin, acetovanillone, vanillic acid), syringyl phenols ( $\mathrm{S}$ : syringealdehyde, acetosyringone, syringic acid), and cinnamyl phenols (C: $p$ coumaric acid, ferulic acid).

In addition, non-lignin-derived phenols were also quantified, including $p$-hydroxybenzenes (P: $p$ hydroxybenzaldehyde, $\quad p$-hydroxybenzophenone, $\quad p$ hydroxybenzoic acid).

\subsection{End-member unmixing}

The concentration of different lignin phenol groups of marine sediment samples and riverine suspended matter samples was used to infer the contribution of gymnosperms and angiosperms to the total lignin-derived OM. The end-member (EM) properties from the literature (as shown in Amon et al., 2012) in the form of C / V and S / V ratios were transformed into relative concentrations of the respective lignin compounds (see Table 7). The linear mixing system of lignin concentrations in the samples can be written in matrix notation as

$\mathbf{X}=\mathbf{A S}+\mathbf{R}$.

$\mathbf{X}$ represents a $n$-by- $m$ matrix of $n$ samples and $m$ of lignin compounds. A ( $n$ by $l$ ) denotes the mixing coefficients of $l$ EMs for the $n$ samples. The $m$ EM properties (lignin concentrations) for the $l$ EMs are represented by matrix $\mathbf{S}(l$ by $m)$. $\mathbf{R}(n$ by $m$ ) denotes the residual matrix. This linear problem can be solved using non-negative least-squares fitting (NNLSQ; Löfberg, 2004). Since the mixing coefficients must be positive and the abundances must add up to unity, a non-negativity constraint $(\mathbf{A} \geq 0)$ and a sum-to-one constraint for the rows in $\mathbf{A}$ were defined. Because the relative abundances of lignin represent a closed data set, we performed the centered-log-ratio transformation (Aitchison, 1982 ) to bring the data $\mathbf{X}$ into real space. We implemented a Monte Carlo simulation with 500 iterations, each with a randomized first guess within the constraints formulated above. The resulting probability density function of possible solutions for each sample and EM contribution is characterized by its median and the interval containing $90 \%$ of the possible solutions.

\section{Results}

\subsection{General characteristics and elemental composition}

The surface water TSM concentrations showed strong spatial (within the delta) and temporal (seasonal/annual) variability (Table 2). The concentrations varied from 3.1 to $174.9 \mathrm{mg} \mathrm{L}^{-1}$ in 2009 and from 3.5 to $32.2 \mathrm{mg} \mathrm{L}^{-1}$ in 2010. The maximum value of $174.9 \mathrm{mg} \mathrm{L}^{-1}$ in 2009 of sample 17 (Fig. 1b, Table S2 in the Supplement) was determined just offshore close to the shore of the Bykovsky Peninsula in shallow water depth. The particulate organic carbon (POC) 
Table 2. Total suspended matter (TSM) concentrations in Lena Delta surface waters (2009 to 2011) and atomic particulate organic carbon (POC) to particulate total nitrogen (PN) ratios. Note that for August 2009 there are only $n=20$ samples for TSM $\left(\mathrm{mg} \mathrm{L}^{-1}\right)$ and POC (wt\%), because the GF/F filter weight of sample 19 was not determined. The atomic POC : PN ratio of sample 19 was therefore calculated based on the filtered water volume (POC in $\mathrm{m} \mathrm{L}^{-1}$ ).

\begin{tabular}{lrrrr}
\hline & $\begin{array}{r}\text { TSM } \\
{\left[\mathrm{mg} \mathrm{L}^{-1}\right]}\end{array}$ & $\begin{array}{r}\left.\text { POC* }^{*} \mathrm{mg} \mathrm{L}^{-1}\right] \\
\text { TSM Aug 2009 }\end{array}$ & $\begin{array}{r}\text { POC }^{*} \\
{[\mathrm{wt} \%]}\end{array}$ & $\begin{array}{r}\text { Atomic } \\
\text { POC }: \text { PN* }^{*}\end{array}$ \\
Mean & 28.50 & 1.21 & 7.2 & $n=21$ \\
Median & 14.94 & 0.83 & 4.7 & 9.6 \\
Min & 3.10 & 0.35 & 1.9 & 9.2 \\
Max & 174.92 & 7.24 & 37.7 & 19.3 \\
TSM July/Aug 2010 & $n=15$ & $n=13$ & $n=13$ & $n=13$ \\
Mean & 19.85 & 0.57 & 3.05 & 7.6 \\
Median & 19.88 & 0.47 & 3.05 & 7.8 \\
Min & 3.52 & 0.15 & 1.42 & 3.7 \\
Max & 32.23 & 1.30 & 4.74 & 10.3 \\
TSM late May 2011 & & & & \\
Sample 37 & 494.00 & 8.20 & 1.66 & 7.5 \\
\hline
\end{tabular}

* From Winterfeld and Mollenhauer (2014), submitted as companion paper).

concentrations and POC to particulate nitrogen $(\mathrm{PN})$ ratios are from the companion paper (Winterfeld and Mollenhauer, 2014) and additionally given in Table 2 . The sample taken in 2011 shortly after the ice breakup off Samoylov Island (sample ID 37) showed with $494 \mathrm{mg} \mathrm{L}^{-1}$ the highest TSM loads determined during this study.

OC and TN contents of first terrace soil samples varied strongly within individual riverbank bluffs and between the bluffs. The OC contents ranged from 1.02 to $17.14 \mathrm{wt} \%$ and the TN contents from 0.03 to $0.45 \mathrm{wt} \%$ (Table 3, Fig. S6 in the Supplement). The highest values (>10 wt \% OC) were not necessarily only found in the topsoil layers, as they were also found within bluff profiles associated with layers containing plant remains like twigs and leaves. Lower OC and TN contents $(<2 \mathrm{wt} \%$ and $<0.1 \mathrm{wt} \%$, respectively) were found in layers with high sand contents. The atomic OC to TN ratios (OC: TN) of these samples show a similar distribution pattern. The ratios varied from 21.7 to 68 , with the highest values $(>40)$ in samples rich in plant remains.

Buor Khaya Bay surface sediments showed generally lower OC and TN contents than observed for the first and third delta terraces (Table 3), ranging from 1.67 to $2.47 \mathrm{wt} \%$ and from 0.09 to $0.18 \mathrm{wt} \%$, respectively. The highest $\mathrm{OC}$ and $\mathrm{TN}$ contents $(2.47 \mathrm{wt} \% \mathrm{OC}$ and $0.18 \mathrm{wt} \% \mathrm{TN})$ were analyzed for sample L09-34 off Muostakh Island (see Fig. 1b). The island is mainly composed of Pleistocene Yedoma deposits and highly affected by coastal erosion providing a lot of particulate matter throughout the open water season. The highest OC: TN ratio of 20.9 was determined off the Sardakh-Trofimovskaya channel system (sample L1036; see Fig. 1b, Table 3), where the majority of the Lena River water and sediment discharge occurs.
Table 3. Organic carbon (OC), total nitrogen $(\mathrm{TN})$, and atomic OC: TN ratios of the Lena Delta soil samples (first and third terrace) and Buor Khaya Bay surface sediments.

\begin{tabular}{lccr}
\hline Sample code & OC [wt \%] & TN [wt \%] & $\begin{array}{r}\text { Atomic } \\
\text { OC: TN }\end{array}$ \\
\hline \multicolumn{4}{c}{ Lena Delta first terrace bulk, $n=19$} \\
\hline Mean & 7.48 & 0.21 & 38.5 \\
Median & 7.61 & 0.24 & 35.1 \\
Min & 1.02 & 0.03 & 21.7 \\
Max & 17.14 & 0.45 & 68.0 \\
\hline \multicolumn{4}{c}{ Lena Delta third terrace (Kurungnakh Island) } \\
\hline S29 (unit V) & 3.76 & 0.19 & 19.4 \\
S17 (unit IVb) & 1.97 & 0.38 & 5.2 \\
S13 (unit IVa) & 1.69 & 0.19 & 9.1 \\
S22D (unit III) & 6.91 & 0.54 & 12.8 \\
S45 (unit III) & 3.72 & 0.31 & 12.1 \\
\hline \multicolumn{4}{c}{ Buor Khaya Bay surface sediments } \\
\hline L09-34 & 2.47 & 0.18 & 15.7 \\
L10-23 & 2.33 & 0.17 & 16.4 \\
L10-24 & 1.88 & 0.15 & 14.7 \\
L10-25 & 1.93 & 0.16 & 11.7 \\
L10-36 & 1.67 & 0.09 & 20.9 \\
\hline
\end{tabular}

* From Wetterich et al. (2008).

\section{2 $\mathrm{CuO}$ oxidation products}

Tables 4 and 5 summarize the sediment- and OC-normalized $\mathrm{CuO}$ product yields of samples presented in this study. Yields of individual samples can be found in the supplementary material (Tables S4 and S5).

\subsubsection{Sediment- and carbon-normalized $\mathrm{CuO}$ oxidation yields}

On average the plant samples exhibit the highest $\mathrm{V}, \mathrm{S}$, $\mathrm{C}$, and $\mathrm{P}$ phenol yields per gram dried sediment/plant tissue (dws), i.e., $\Sigma 8$ (sediment-normalized sum of $\mathrm{V}, \mathrm{S}$, and $\mathrm{C}$ phenols) ranging from 4.64 to $17.08 \mathrm{mg} \mathrm{g}^{-1} \mathrm{dws}$. Only a few soil samples of the first terrace reach similar yields. Generally first terrace $\Sigma 8$ contents vary from 0.04 to $7.10 \mathrm{mg} \mathrm{g}^{-1} \mathrm{dws}$ (mean $\Sigma 81.93 \mathrm{mg} \mathrm{g}^{-1} \mathrm{dws}$ ). Contents from the third terrace on Kurungnakh Island are generally lower $\left(<2.0 \mathrm{mg} \mathrm{g}^{-1} \mathrm{dws}\right)$, except for the two Pleistocene samples from unit III ( $\Sigma 8$ is $1.81 \mathrm{mg} \mathrm{g}^{-1} \mathrm{dws}$ for both samples). Suspended matter from 2009 to 2011 and surface sediment samples have $\mathrm{CuO}$ product yields in a similar range from 0.04 to $0.47 \mathrm{mg} \mathrm{g}^{-1} \mathrm{dws}$ over all phenol groups. In Buor Khaya Bay the yields decrease with distance from the delta. Highest values were determined in front of the Sardakh-Trofimovskaya channel and offshore of Muostakh Island. As already shown for the OC and TN contents above, the V, S, C, and P phenol 
Table 4. Sediment-normalized yields of $\mathrm{CuO}$ oxidations products of Lena Delta soils, total suspended matter (TSM), surface sediments, and vegetation samples in milligram per gram dry weight sediment $\left(\mathrm{mg} \mathrm{g}^{-1} \mathrm{dws}\right)$. Trivial names of analyzed plant species in brackets. $\mathrm{V}$ : vanillyl phenols (sum of vanillin, acetovanillone, vanillic acid); S: syringyl phenols (sum of syringealdehyde, acetosyringone, syringic acid); $\mathrm{C}$ : cinnamyl phenols (sum of $p$-coumaric acid, ferulic acid); $\Sigma 8$ : sum of V, S, and $\mathrm{C}$ phenols; P: $p$-hydroxybenzenes (sum of $p$-hydroxybenzaldehyde, $p$-hydroxyacetophenone, $p$ hydroxybenzoic acid); Pn: $p$-hydroxyacetophenone.

\begin{tabular}{|c|c|c|c|c|c|c|}
\hline & $\mathrm{V}$ & $S$ & $\mathrm{C}$ & $\Sigma 8$ & $\mathrm{P}$ & $\mathrm{Pn}$ \\
\hline & \multicolumn{6}{|c|}{$\left[\mathrm{mg} \mathrm{g}^{-1} \mathrm{dws}\right]$} \\
\hline \multicolumn{7}{|c|}{ Lena Delta first terrace bulk, $n=19$} \\
\hline Mean & 0.75 & 0.74 & 0.43 & 1.93 & 0.84 & 0.13 \\
\hline Median & 0.73 & 0.66 & 0.31 & 1.60 & 0.69 & 0.10 \\
\hline Min & 0.04 & 0.04 & 0.02 & 0.09 & 0.05 & 0.00 \\
\hline Max & 2.41 & 2.82 & 1.87 & 7.10 & 3.68 & 0.42 \\
\hline \multicolumn{7}{|c|}{ Lena Delta third terrace (Kurungnakh Island) } \\
\hline S29 (unit V) & 0.24 & 0.17 & 0.21 & 0.63 & 0.13 & 0.04 \\
\hline S17 (unit IVb) & 0.17 & 0.14 & 0.06 & 0.37 & 0.15 & 0.02 \\
\hline S13 (unit IVa) & 0.13 & 0.11 & 0.06 & 0.29 & 0.12 & 0.02 \\
\hline S22D (unit III) & 0.53 & 0.69 & 0.59 & 1.81 & 0.97 & 0.13 \\
\hline S45 (unit III) & 0.54 & 0.73 & 0.54 & 1.81 & 0.62 & 0.09 \\
\hline \multicolumn{7}{|c|}{ TSM Aug 2009, $n=7$} \\
\hline Mean & 0.16 & 0.07 & 0.04 & 0.27 & 0.14 & 0.05 \\
\hline Median & 0.17 & 0.07 & 0.03 & 0.27 & 0.15 & 0.05 \\
\hline Min & 0.10 & 0.04 & 0.02 & 0.17 & 0.07 & 0.04 \\
\hline Max & 0.22 & 0.17 & 0.08 & 0.47 & 0.21 & 0.07 \\
\hline \multicolumn{7}{|c|}{ TSM July/Aug 2010, $n=8$} \\
\hline Mean & 0.21 & 0.08 & 0.04 & 0.32 & 0.16 & 0.04 \\
\hline Median & 0.20 & 0.08 & 0.03 & 0.31 & 0.15 & 0.05 \\
\hline Min & 0.08 & 0.03 & 0.01 & 0.12 & 0.07 & 0.02 \\
\hline Max & 0.34 & 0.14 & 0.06 & 0.53 & 0.30 & 0.06 \\
\hline \multicolumn{7}{|c|}{ TSM late May 2011, $n=1$} \\
\hline & 0.47 & 0.24 & 0.12 & 0.83 & 0.21 & 0.24 \\
\hline \multicolumn{7}{|c|}{ Buor Khaya Bay surface sediments } \\
\hline L09-34 & 0.33 & 0.14 & 0.05 & 0.52 & 0.13 & 0.07 \\
\hline L10-23 & 0.41 & 0.18 & 0.06 & 0.64 & 0.15 & 0.08 \\
\hline L10-24 & 0.16 & 0.07 & 0.03 & 0.25 & 0.07 & 0.05 \\
\hline L10-25 & 0.11 & 0.05 & 0.02 & 0.18 & 0.05 & 0.05 \\
\hline L10-36 & 0.28 & 0.12 & 0.04 & 0.45 & 0.12 & 0.07 \\
\hline \multicolumn{7}{|c|}{ Vegetation samples } \\
\hline $\begin{array}{l}\text { Aulacomnium turgidum } \\
\text { (moss) }\end{array}$ & 1.57 & 1.63 & 1.44 & 4.64 & 3.64 & 1.74 \\
\hline $\begin{array}{l}\text { Carex spp. } \\
\text { (sedge) }\end{array}$ & 4.13 & 6.24 & 6.71 & 17.08 & 3.58 & 0.70 \\
\hline $\begin{array}{l}\text { Ledum palustre } \\
\text { (wild rosemary) }\end{array}$ & 2.76 & 2.59 & 3.62 & 8.97 & 3.51 & 0.82 \\
\hline $\begin{array}{l}\text { Betula nana } \\
\text { (dwarf birch) }\end{array}$ & 5.78 & 7.43 & 3.19 & 16.40 & 1.27 & 0.34 \\
\hline $\begin{array}{l}\text { Salix } \\
\text { (willow) }\end{array}$ & 6.22 & 4.21 & 2.17 & 12.59 & 2.19 & 0.75 \\
\hline $\begin{array}{l}\text { Larix needles } \\
\text { (larch) }\end{array}$ & 7.93 & 1.41 & 7.32 & 16.66 & 5.48 & 1.46 \\
\hline
\end{tabular}

yields also vary strongly within the first delta terrace soils samples and TSM samples. In general, the P and V phenol groups were most abundant, followed by the $\mathrm{S}$ and $\mathrm{C}$ phenol groups.

An overview of the $\mathrm{CuO}$ yield per $100 \mathrm{mg} \mathrm{OC}(\Lambda 8)$ for the different locations and sample types is presented in Fig. 2. The overall patterns described for the sedimentnormalized yields are also true for the carbon-normalized yields. The highest $\Lambda 8$ were analyzed in samples from the first and third delta terraces varying between 0.78 and $8.81 \mathrm{mg} 100 \mathrm{mg}^{-1} \mathrm{OC}$ over all phenol groups (Table 5). The $\Lambda 8$ were lower in TSM from the summers 2009 and 2010 $\left(<1.5 \mathrm{mg} 100 \mathrm{mg}^{-1} \mathrm{OC}\right)$ and notably higher for the spring flood sample from $2011\left(5.16 \mathrm{mg} 100 \mathrm{mg}^{-1}\right.$ OC) as well as for the surface sediments of Buor Khaya Bay (mean value $1.96 \mathrm{mg} 100 \mathrm{mg}^{-1} \mathrm{OC}$ ). The amounts of individual phenol groups are also different between the delta soil samples, the TSM, and the surface sediments samples. Generally the P and $\mathrm{V}$ phenols were most abundant, followed by $\mathrm{S}$ and $\mathrm{C}$ phenols (Fig. 2). Again, the two samples from the third terrace from unit III were slightly different. Here, the $\mathrm{S}$ phenols were most abundant, followed by the $\mathrm{P}, \mathrm{V}$, and $\mathrm{C}$ phenols. The distribution of V, S, C, and P phenols in the summer TSM samples of 2009 and 2010 were similar with the V and P phenols being most abundant. The spring flood sample from 2011 and the surface sediment samples were comparable, with $\mathrm{V}$ and S phenols having the highest yields (Fig. 2).

\subsubsection{Vegetation source parameters}

The bulk samples of the first delta terrace show a broad range of C / V and S / V ratios ( 0.16 to 1.16 for C / V and 0.58 to 1.58 for S / V, Tables 5 and S5 and Fig. S7). As shown in Fig. $4 \mathrm{~b}$ the values fall on a mixing line between woody gymnosperm and non-woody angiosperm tissues. The $\mathrm{P} / \mathrm{V}$ ratios show a similar range of variation. The samples from the third terrace have comparable ratios to those from the first terrace, with the highest $\mathrm{C} / \mathrm{V}$ and $\mathrm{S} / \mathrm{V}$ ratios determined for the two Pleistocene samples from unit III. The values of the TSM samples taken in summer and spring and in three consecutive years are within the same range. Mean C / V ratios were $0.21,0.18$, and 0.25 and mean $\mathrm{S} / \mathrm{V}$ ratios were $0.44,0.38$, and 0.5 for the years 2009,2010 , and 2011, respectively. The $\mathrm{P} / \mathrm{V}$ ratios were higher in the summers of 2009 and 2010 ( 0.65 to 1.25 and 0.62 to 0.89 , respectively) than in spring 2011 (0.44). The C / V, S / V, and P / V ratios vary only slightly in the Buor Khaya surface sediments and are generally in the range of the TSM samples and lower than the mean of the first delta terrace and the third terrace soil samples. Except for the sample of larch needles, the C / V, $\mathrm{S} / \mathrm{V}$, and $\mathrm{P} / \mathrm{V}$ ratios of the vegetation samples reflect their tissue and plant origin closely (Figs. $4 \mathrm{~b}$ and 5). 
Table 5. Carbon-normalized yields of $\mathrm{CuO}$ oxidation products of Lena Delta soils, surface water total suspended matter (TSM), and surface sediments in milligrams per 100 milligrams of organic carbon [mg $100 \mathrm{mg}^{-1} \mathrm{OC}$ ] and related lignin parameters. Abbreviations for phenol groups are the same as in Table 4. Ad / $\mathrm{Al}_{\mathrm{V}}$ : acid to aldehyde ratio of vanillyl phenols; $\mathrm{Ad}_{\mathrm{A}} / \mathrm{Al}_{\mathrm{S}}$ : acid to aldehyde ratios of syringyl phenols; C / V: cinnamyl to vanillyl phenols; S / V: syringyl to vanillyl phenols; P / V: p-hydroxybenzenes to vanillyl phenols; Pn / P: $p$-hydroxyacetophenone to $p$-hydroxybenzenes. Not determined denoted by $\mathrm{n} / \mathrm{d}$.

\begin{tabular}{|c|c|c|c|c|c|c|c|c|c|c|c|c|}
\hline & $\mathrm{V}$ & $\mathrm{S}$ & $\mathrm{C}$ & $\Lambda 8$ & $\mathrm{P}$ & Pn & $\mathrm{Ad} / \mathrm{Al}_{\mathrm{V}}$ & $\mathrm{Ad} / \mathrm{Al}_{\mathrm{S}}$ & $\mathrm{C} / \mathrm{V}$ & $\mathrm{S} / \mathrm{V}$ & $\mathrm{P} / \mathrm{V}$ & $\mathrm{Pn} / \mathrm{P}$ \\
\hline \multicolumn{13}{|c|}{$\left[\mathrm{mg} 100 \mathrm{mg}^{-1} \mathrm{OC}\right]$} \\
\hline \multicolumn{13}{|c|}{ Lena Delta first terrace bulk, $n=19$} \\
\hline Mean & 1.08 & 1.02 & 0.54 & 2.64 & 0.99 & 0.14 & 0.76 & 0.64 & 0.53 & 0.96 & 1.05 & 0.14 \\
\hline Median & 0.91 & 0.88 & 0.47 & 2.18 & 0.95 & 0.13 & 0.77 & 0.62 & 0.48 & 0.92 & 1.08 & 0.14 \\
\hline Min & 0.30 & 0.31 & 0.14 & 0.78 & 0.33 & 0.03 & 0.41 & 0.37 & 0.16 & 0.58 & 0.24 & 0.07 \\
\hline $\operatorname{Max}$ & 3.50 & 3.62 & 1.69 & 8.81 & 2.38 & 0.27 & 1.19 & 1.01 & 1.16 & 1.58 & 1.53 & 0.22 \\
\hline \multicolumn{13}{|c|}{ Lena Delta third terrace (Kurungnakh Island) } \\
\hline S29 (unit V) & 0.73 & 0.37 & 0.57 & 1.66 & 0.35 & 0.10 & 0.43 & 0.58 & 0.79 & 0.51 & 0.49 & 0.28 \\
\hline S17 (unit IVb) & 1.05 & 0.55 & 0.28 & 1.89 & 0.75 & 0.11 & 0.46 & 0.51 & 0.27 & 0.53 & 0.71 & 0.15 \\
\hline S13 (unit IVa) & 0.87 & 0.55 & 0.33 & 1.74 & 0.74 & 0.12 & 0.47 & 0.49 & 0.38 & 0.63 & 0.85 & 0.16 \\
\hline S22D (unit III) & 0.80 & 0.96 & 0.86 & 2.62 & 1.40 & 0.18 & 0.48 & 0.38 & 1.07 & 1.20 & 1.75 & 0.13 \\
\hline S45 (unit III) & 1.52 & 1.88 & 1.46 & 4.87 & 1.68 & 0.24 & 0.35 & 0.31 & 0.96 & 1.24 & 1.10 & 0.14 \\
\hline \multicolumn{13}{|c|}{ TSM Aug 2009, $n=7$} \\
\hline Mean & 0.63 & 0.27 & 0.13 & 1.03 & 0.54 & 0.05 & 1.71 & 0.99 & 0.21 & 0.44 & 0.85 & 0.10 \\
\hline Median & 0.62 & 0.26 & 0.11 & 0.99 & 0.58 & 0.05 & 1.36 & 0.98 & 0.19 & 0.41 & 0.81 & 0.09 \\
\hline Min & 0.43 & 0.17 & 0.09 & 0.73 & 0.29 & 0.04 & 0.68 & 0.52 & 0.14 & 0.25 & 0.65 & 0.07 \\
\hline $\operatorname{Max}$ & 0.80 & 0.48 & 0.24 & 1.35 & 0.71 & 0.07 & 3.97 & 1.51 & 0.39 & 0.77 & 1.25 & 0.13 \\
\hline \multicolumn{13}{|c|}{ TSM July/Aug 2010, $n=8$} \\
\hline Mean & 0.70 & 0.27 & 0.12 & 1.09 & 0.53 & 0.05 & 1.36 & 0.81 & 0.18 & 0.38 & 0.77 & 0.09 \\
\hline Median & 0.74 & 0.30 & 0.14 & 1.19 & 0.51 & 0.05 & 1.44 & 0.87 & 0.18 & 0.39 & 0.81 & 0.09 \\
\hline Min & 0.28 & 0.09 & 0.05 & 0.42 & 0.25 & 0.02 & 0.69 & 0.48 & 0.15 & 0.32 & 0.62 & 0.07 \\
\hline $\operatorname{Max}$ & 0.93 & 0.37 & 0.16 & 1.44 & 0.81 & 0.06 & 2.02 & 1.11 & 0.20 & 0.45 & 0.89 & 0.11 \\
\hline \multicolumn{13}{|c|}{ TSM late May 2011, $n=1$} \\
\hline & 2.94 & 1.47 & 0.74 & 5.16 & 1.29 & 0.24 & 0.32 & 0.32 & 0.25 & 0.50 & 0.44 & 0.19 \\
\hline \multicolumn{13}{|c|}{ Buor Khaya Bay surface sediments } \\
\hline L09-34 & 1.34 & 0.55 & 0.21 & 2.09 & 0.52 & 0.07 & 1.75 & 1.37 & 0.15 & 0.41 & 0.39 & 0.13 \\
\hline L10-23 & 1.74 & 0.76 & 0.26 & 2.76 & 0.65 & 0.08 & 1.36 & 1.16 & 0.15 & 0.44 & 0.37 & 0.12 \\
\hline L10-24 & 0.84 & 0.36 & 0.14 & 1.33 & 0.37 & 0.05 & 1.19 & 1.06 & 0.16 & 0.43 & 0.44 & 0.14 \\
\hline L10-25 & 0.57 & 0.25 & 0.12 & 0.94 & 0.28 & 0.05 & 0.98 & 0.85 & 0.21 & 0.45 & 0.50 & 0.16 \\
\hline L10-36 & 1.68 & 0.74 & 0.27 & 2.68 & 0.72 & 0.07 & 1.10 & 0.77 & 0.16 & 0.44 & 0.43 & 0.10 \\
\hline \multicolumn{13}{|c|}{ Vegetation samples } \\
\hline Aulacomnium turgidum (moss) & $\mathrm{n} / \mathrm{d}$ & $\mathrm{n} / \mathrm{d}$ & $\mathrm{n} / \mathrm{d}$ & $\mathrm{n} / \mathrm{d}$ & $\mathrm{n} / \mathrm{d}$ & $\mathrm{n} / \mathrm{d}$ & 0.67 & 0.80 & 0.92 & 1.04 & 2.32 & 0.48 \\
\hline Carex spp. (sedges) & $\mathrm{n} / \mathrm{d}$ & $\mathrm{n} / \mathrm{d}$ & $\mathrm{n} / \mathrm{d}$ & $\mathrm{n} / \mathrm{d}$ & $\mathrm{n} / \mathrm{d}$ & $\mathrm{n} / \mathrm{d}$ & 0.23 & 0.22 & 1.63 & 1.51 & 0.87 & 0.20 \\
\hline Ledum palustre (wild rosemary) & $\mathrm{n} / \mathrm{d}$ & $\mathrm{n} / \mathrm{d}$ & $\mathrm{n} / \mathrm{d}$ & $\mathrm{n} / \mathrm{d}$ & $\mathrm{n} / \mathrm{d}$ & $\mathrm{n} / \mathrm{d}$ & 0.41 & 0.49 & 1.31 & 0.94 & 1.27 & 0.23 \\
\hline Betula nana (dwarf birch) & $\mathrm{n} / \mathrm{d}$ & $\mathrm{n} / \mathrm{d}$ & $\mathrm{n} / \mathrm{d}$ & $\mathrm{n} / \mathrm{d}$ & $\mathrm{n} / \mathrm{d}$ & $\mathrm{n} / \mathrm{d}$ & 0.18 & 0.13 & 0.55 & 1.29 & 0.22 & 0.27 \\
\hline Salix (willow) & $\mathrm{n} / \mathrm{d}$ & $\mathrm{n} / \mathrm{d}$ & $\mathrm{n} / \mathrm{d}$ & $\mathrm{n} / \mathrm{d}$ & $\mathrm{n} / \mathrm{d}$ & $\mathrm{n} / \mathrm{d}$ & 0.20 & 0.24 & 0.35 & 0.68 & 0.35 & 0.34 \\
\hline Larix needles (larch) & $\mathrm{n} / \mathrm{d}$ & $\mathrm{n} / \mathrm{d}$ & $\mathrm{n} / \mathrm{d}$ & $\mathrm{n} / \mathrm{d}$ & $\mathrm{n} / \mathrm{d}$ & $\mathrm{n} / \mathrm{d}$ & 0.14 & 0.87 & 0.92 & 0.18 & 0.69 & 0.27 \\
\hline
\end{tabular}

\subsubsection{Degradation indicators}

The acid to aldehyde ratios of vanillyl and syringyl phenols $(\mathrm{Ad} / \mathrm{Al} \mathrm{V}, \mathrm{S})$ of the first delta terrace vary strongly from moderately degraded ( 0.5 to 0.6$)$ to highly degraded (>0.6) (Figs. 4a and S7, Table 5). Ratios of the third terrace on $\mathrm{Ku}-$ rungnakh Island are generally lower $(<0.6)$ than ratios from the first terrace. Notably, the lowest ratios were analyzed for the oldest sample S45 $(<0.4$, Table 5). Ad / Alv, S ratios of the summer TSM are in the range of the first delta terrace or higher, e.g., varying between 0.68 and 3.97 for $\mathrm{Ad} / \mathrm{Al}$ in 2009 and between 0.69 and 2.02 in 2010. The spring flood 

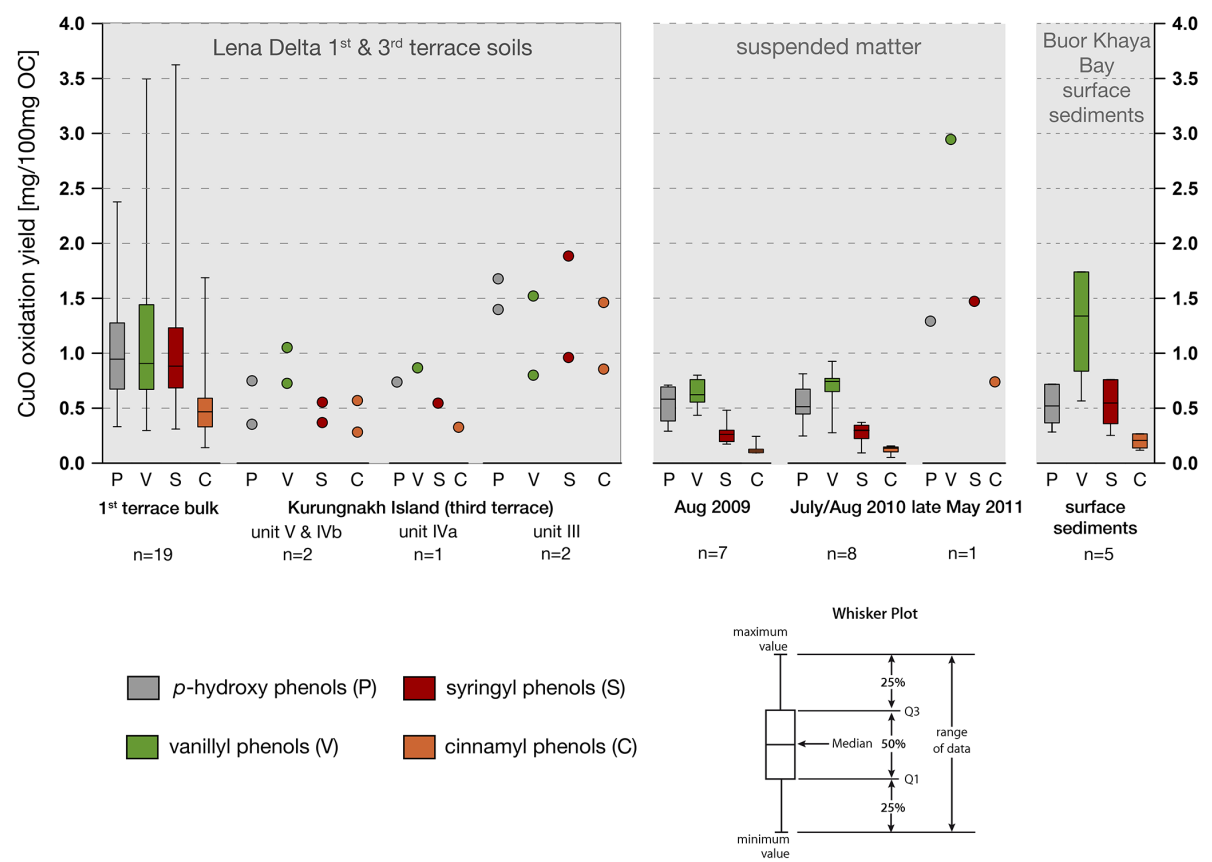

Figure 2. Carbon-normalized yields of phenols groups shown as box-and-whisker plots when the number of samples was large enough and as individual samples for smaller numbers.

sample from 2011 is characterized by one of the lowest ratios of all samples presented here ( 0.32 for both $\mathrm{Ad} / \mathrm{Al} V$ and $\mathrm{Ad} / \mathrm{Al}_{\mathrm{S}}$ ). Buor Khaya Bay surface sediments showed ratios $>0.6$, which are in the range of the first delta terrace and summer TSM samples (0.98-1.75 for Ad / AlV and $0.77-1.37$ for $\left.\mathrm{Ad} / \mathrm{Al}_{\mathrm{S}}\right)$. The highest ratios were analyzed off Muostakh Island (sample L09-34). The vegetation samples have low $\mathrm{Ad} / \mathrm{Al}$, S ratios $(<0.4)$, except for the Larix needles, the herb sample (Ledum palustre), and the moss sample (Aulacomnium turgidum), which have ratios $>0.4$. It is known that different plant species or even different parts of a plant (e.g., mosses and needles, respectively) can have naturally higher acid concentrations, resulting in higher $\mathrm{Ad} / \mathrm{Al}_{\mathrm{V}, \mathrm{S}}(=$ more degraded) even when they are fresh (see Benner et al., 1990). This is most likely also the case for the vegetation samples presented here.

\subsection{End-member unmixing}

The EM unmixing was performed for the TSM and surface sediment samples. The EM properties of moss and peat contribution in this model do not represent the range of values observed in our samples. Fig. 5 shows our Pn / P and P / V ratios in relation to several published values, amongst others the EMs used for moss, soil, and peat.

Therefore, we applied an unmixing model distinguishing between the four major vegetation sources for OM: woody and no-woody gymnosperm and angiosperm tissues. We used C / V and S / V ratios and took the EMs (Table 6) from Amon et al. (2012) and references therein, which covered the
Table 6. End-member ratios taken from the literature used for the unmixing model here and our calculated relative amounts of $\mathrm{V}, \mathrm{S}$, and $\mathrm{C}$ phenols. For abbreviations see description in Table 4 and 5.

\begin{tabular}{lrrrrr}
\hline End member & $\mathrm{C} / \mathrm{V}$ & $\mathrm{S} / \mathrm{V}$ & $\mathrm{V}$ & $\mathrm{S}$ & $\mathrm{C}$ \\
\cline { 4 - 6 } & & & \multicolumn{3}{c}{$[\%]$} \\
\hline \begin{tabular}{l} 
Woody gymnosperm \\
\cline { 4 - 6 }
\end{tabular} & $0.04^{*}$ & $0.03^{*}$ & 0.93 & 0.03 & 0.04 \\
(non-woody gymnosperm & $0.17^{*}$ & $0.04^{*}$ & 0.83 & 0.03 & 0.14 \\
Woody angiosperm & & & & & \\
$\begin{array}{l}\text { Non-woody angiosperm } \\
\text { (leaves, grasses) }\end{array}$ & $0.05^{*}$ & $2.42^{*}$ & 0.29 & 0.70 & 0.01 \\
& & $0.98^{*}$ & 0.37 & 0.37 & 0.26 \\
\hline
\end{tabular}

* End-member ratios from Table 4 in Amon et al. (2011) including Hedges and Mann (1979), Hedges and Parker (1976), Prokushkin et al. (in preparation), Williams et al. (1998).

complete range measured in TSM and surface sediment samples (Fig. 4b).

The median values of the unmixing solutions (obtained by Monte Carlo simulation) of angiosperms (woody + nonwoody) and gymnosperms (woody + non-woody) are shown in Table 7. The relative contributions show a broad range for the summer TSM samples of 2009 and 2010, i.e., gymnosperm contribution varies from 0.24 to 0.69 and from 0.49 to 0.63 , respectively. The low gymnosperm contribution of 0.24 is inferred for sample 17, located off Bykovsky Peninsula (Fig. 1b). The contributions to the Buor Khaya Bay surface sediments vary to a lesser extent from 0.49 to 0.56 for gymnosperms. 
Table 7. Results of unmixing model including relative abundances of V, S, and C phenols; median mixing coefficients; and gymnosperm to angiosperm ratio. See Tables 4 and 5 for abbreviations.

\begin{tabular}{|c|c|c|c|c|c|c|c|c|c|c|}
\hline \multirow[b]{2}{*}{$\begin{array}{l}\text { Sample } \\
\text { code }\end{array}$} & \multirow[b]{2}{*}{$\begin{array}{r}\text { Rel. V } \\
{[\%]}\end{array}$} & \multirow[b]{2}{*}{$\begin{array}{r}\text { Rel. S } \\
{[\%]}\end{array}$} & \multirow[b]{2}{*}{$\begin{array}{r}\text { Rel. C } \\
{[\%]}\end{array}$} & \multicolumn{4}{|c|}{ Median (500 iterations) mixing coefficients } & \multirow[b]{2}{*}{$\begin{array}{l}\text { Median total } \\
\text { gymno-sperm }\end{array}$} & \multirow[b]{2}{*}{$\begin{array}{l}\text { Median total } \\
\text { angio-sperm }\end{array}$} & \multirow[b]{2}{*}{$\begin{array}{l}\text { Proportion of median } \\
\text { gymnosperm/angiosperm }\end{array}$} \\
\hline & & & & $\begin{array}{r}\text { Woody } \\
\text { gymnosperm }\end{array}$ & $\begin{array}{l}\text { Non-woody } \\
\text { gymnosperm }\end{array}$ & $\begin{array}{r}\text { Woody } \\
\text { angiosperm }\end{array}$ & $\begin{array}{l}\text { Non-woody } \\
\text { angiosperm }\end{array}$ & & & \\
\hline 4 & 0.67 & 0.23 & 0.10 & 0.34 & 0.27 & 0.21 & 0.17 & 0.61 & 0.38 & 1.6 \\
\hline 10 & 0.65 & 0.24 & 0.10 & 0.31 & 0.27 & 0.23 & 0.18 & 0.58 & 0.41 & 1.4 \\
\hline 11 & 0.72 & 0.18 & 0.10 & 0.37 & 0.31 & 0.15 & 0.14 & 0.69 & 0.29 & 2.4 \\
\hline 16 & 0.63 & 0.25 & 0.12 & 0.26 & 0.28 & 0.21 & 0.26 & 0.53 & 0.46 & 1.2 \\
\hline 17 & 0.46 & 0.36 & 0.18 & 0.02 & 0.22 & 0.21 & 0.57 & 0.24 & 0.78 & 0.3 \\
\hline \multicolumn{11}{|c|}{ TSM July/Aug 2010} \\
\hline 25 & 0.64 & 0.25 & 0.12 & 0.27 & 0.28 & 0.20 & 0.25 & 0.55 & 0.44 & 1.2 \\
\hline 26 & 0.64 & 0.25 & 0.11 & 0.29 & 0.27 & 0.22 & 0.20 & 0.56 & 0.43 & 1.3 \\
\hline 27 & 0.62 & 0.26 & 0.12 & 0.24 & 0.27 & 0.20 & 0.28 & 0.52 & 0.48 & 1.1 \\
\hline 32 & 0.66 & 0.22 & 0.12 & 0.28 & 0.30 & 0.16 & 0.25 & 0.58 & 0.41 & 1.4 \\
\hline \multicolumn{11}{|c|}{ TSM late May 2011} \\
\hline 37 & 0.57 & 0.29 & 0.14 & 0.17 & 0.25 & 0.19 & 0.37 & 0.43 & 0.57 & 0.8 \\
\hline \multicolumn{11}{|c|}{ Buor Khaya Bay surface sediments } \\
\hline L09-34 & 0.64 & 0.26 & 0.10 & 0.31 & 0.25 & 0.25 & 0.18 & 0.56 & 0.44 & 1.3 \\
\hline L10-23 & 0.63 & 0.28 & 0.09 & 0.30 & 0.25 & 0.28 & 0.17 & 0.55 & 0.45 & 1.2 \\
\hline L10-24 & 0.63 & 0.27 & 0.10 & 0.28 & 0.26 & 0.26 & 0.20 & 0.54 & 0.46 & 1.2 \\
\hline L10-25 & 0.61 & 0.27 & 0.13 & 0.23 & 0.26 & 0.21 & 0.29 & 0.49 & 0.50 & 1.0 \\
\hline L10-36 & 0.63 & 0.27 & 0.10 & 0.29 & 0.25 & 0.27 & 0.19 & 0.54 & 0.46 & 1.2 \\
\hline
\end{tabular}

\section{Discussion}

\subsection{Spatial and temporal patterns of Lena Delta total suspended matter}

\subsubsection{Suspended sediment distribution and particulate lignin biomarker abundances}

Surface water suspended particulate matter sampled in highly dynamic systems like a river delta can only provide very local snapshots of the suspended matter properties. The Lena Delta is characterized by a dynamic hydrology and fast changes in local conditions of erosion and accumulation, which are related to changes in water velocity and turbidity that lead to channel migration and branching (Fedorova et al., 2015). Longer time series covering several years and seasons are needed to observe catchment-related changes in these properties independent of the natural variability. Further, it is important to consider the season of TSM sampling: in the summer season in July and August the active layer depth is deepest; riverbank erosion along the delta channels is very pronounced; and streams draining ice complex deposits and thermokarst lakes transport more sediment, providing local delta-derived sediment to the river surface water. During the ice breakup and associated spring flood in late May to early June, the soils in the delta and northern catchment are still frozen. Riverbanks and bluffs are eroded by ice jamming against the riverbank and by thermal abrasion by relatively warmer Lena River water. The eroded material mixes with sediment transported from the south and is exported with the flood to the Laptev Sea coastal zone.

Our TSM concentrations from July/August 2009 and 2010 (mean values are 28.5 and $19.85 \mathrm{mg} \mathrm{L}^{-1}$, respectively) showed a high spatial and interannual variability (Fig. 3ac). Surface water TSM from the Lena Delta has been sampled during several expeditions in the past, mainly during the summer season, and by the Federal Service of Hydrometeorology and Environmental Monitoring of Russia (Roshydromet) at several stations throughout the delta (see $\mathrm{Fe}$ dorova et al., 2015). All concentrations measured in this study were well within the range of published values of samples taken in July to early September between 1989 and 2003 (16.5 to > $30 \mathrm{mg} \mathrm{L}^{-1}$; Cauwet and Sidorov, 1996; Rachold and Hubberten, 1999). Our single measurement from the spring flood in late May 2011 taken offshore of Samoylov Island $\left(72.37^{\circ} \mathrm{N}, 126.47^{\circ} \mathrm{E}\right)$ was more than 10 times higher $\left(494 \mathrm{mg} \mathrm{L}^{-1}\right)$ than the summer values. It clearly reflects the distinct seasonality of the hydrograph of the 
Lena River, where more than $50 \%$ of the annual TSM export happens during the spring freshet (Cauwet and Sidorov, 1996; Rachold et al., 2004). The only additional spring flood values from the Lena River we are aware of are provided by the Arctic Great Rivers Observatory Project (A-GRO, www.arcticgreatrivers.org, version $1.4,2012)$ and are taken at the Zhigansk gauging station $\left(66.77^{\circ} \mathrm{N}, 123.37^{\circ} \mathrm{E}\right)$, approximately $900 \mathrm{~km}$ south of the Lena Delta. The TSM concentrations reported by Arctic GRO for late May/early June 2004 to 2010 are lower than our measurement, varying from 28.8 to $221 \mathrm{mg} \mathrm{L}^{-1}$. The higher Lena Delta value from 2011 could be a result of the flood wave eroding and entraining more sedimentary material on its way to the north. Despite the low sample resolution for the time of the spring flood, our single delta sample and the few samples from Zhigansk (A-GRO) highlight the strong seasonal differences in river supply suspended sediments and the need for more sampling campaigns during the spring freshet to improve flux estimates of terrestrial OM to Laptev Sea.

We chose to only discuss the carbon-normalized $(\Lambda 8)$ yields instead of sediment-normalized $(\Sigma 8)$ results of our TSM samples, because during sample preparation some glass fiber filter material was included in the analyzed sample, thus biasing the sediment-normalized calculation (described above in Sect. 2.3). Like the TSM concentrations discussed above, the $\Lambda 8$ concentrations reflect the strong seasonality of the Lena River hydrograph. $\Lambda 8$ concentrations were similar in the summers 2009 and 2010 (mean $\Lambda 81.03$ and $1.09 \mathrm{mg} 100 \mathrm{mg}^{-1} \mathrm{OC}$, respectively; Table 5) and about 5

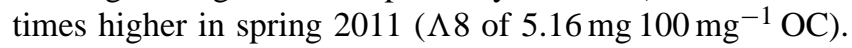
The normalization to the total organic carbon measured in our TSM samples, which is a mixture of terrestrial- and plankton-derived organic matter, most likely alters the ratio of $\Lambda 8$ to organic carbon in the sample. The presence of aquatic plankton-derived OM dilutes carbon-normalized lignin concentrations lowering $\Lambda 8$ values relative to those from terrestrial source material. The particulate organic carbon to nitrogen ratios (POC:PN) from 2009 to 2011 (Table 2, from Winterfeld and Mollenhauer, 2014, companion paper) suggest that a considerable amount of nitrogen-rich plankton-derived OM is present in our TSM samples. This is further supported by lower $\delta^{13} \mathrm{C}$ values determined for the bulk POM taken in summer 2009 and 2010 (mean $\delta^{13} \mathrm{C}$ of $-30.6 \%$ and $-29.2 \%$, respectively; Winterfeld and Mollenhauer, 2014, companion paper), which suggests a considerable fraction of freshwater plankton utilizing dissolved inorganic carbon depleted in ${ }^{13} \mathrm{C}$ is present in the surface water, as has been shown for the Lena and Yenisey rivers (e.g., Alling et al., 2012; Galimov et al., 2006; Rachold and Hubberten, 1999). Furthermore, in part 1 of this paper, we show estimated fractions of phytoplankton OM contributing to the bulk POM of the same water samples analyzed here for lignin phenol composition using two simple binary mixing models between phytoplankton- and soil-derived POM based on the POC : $\mathrm{PN}$ ratios and the $\delta^{13} \mathrm{C}$ values. For the lignin phenol samples presented here the phytoplankton fractions ranged form 47 to $77 \%$ and 23 to $53 \%$ based on POC: $\mathrm{PN}$ ratios and $\delta^{13} \mathrm{C}$ values, respectively (Winterfeld and Mollenhauer, 2014, companion paper). However, low POC : PN ratios in combination with elevated $\Lambda 8$ values were also found in a river-dominated estuary in the US by Goñi et al. (2003). Here, the authors suggested that contributions of bacterial nitrogen-rich exudation products generated during vascular plant decomposition (Rice and Hanson, 1984) could be responsible for the lower POC: PN ratios (Goñi et al., 2003). However, OC : TN ratios from Lena Delta soils presented in this study are $>20$ (Table 3 ) and from soils along a northsouth transect in the Lena watershed $\left(73.5^{\circ}-69.5^{\circ} \mathrm{N}\right)$ are $>13.5$ (Zubrzycki et al., 2012), which points to less degraded soil OM and, together with the low POM $\delta{ }^{13} \mathrm{C}$ values (Winterfeld and Mollenhauer, 2014, companion paper), supports the idea of higher phytoplankton OM contributions to our TSM samples instead of highly degraded mineral soil.

\subsubsection{Tracers of vegetation sources from the Lena River catchment}

The C / V and S / V ratios allow for distinguishing between different vegetation sources, such as woody and non-woody tissues as well as gymnosperm and angiosperm tissues, respectively (e.g., Hedges and Mann, 1979; Hedges et al., 1982; Kuzyk et al., 2008). As shown in Fig. 4b, the TSM values of 2009-2011 reflect a mixture of woody gymnosperm and non-woody angiosperm vegetation sources. However, cinnamyl phenols are known to degrade relatively fast during early diagenesis resulting in decreased C / V ratios, while $\mathrm{S} / \mathrm{V}$ ratios seem to be only moderately altered (Benner et al., 1990; Opsahl and Benner, 1995). This implies that our low $\mathrm{C} / \mathrm{V}$ ratios do not unambiguously reflect high woody gymnosperm contribution. As a result, any estimate of woody gymnosperm contribution based on $\mathrm{C} / \mathrm{V}$ ratios alone must be considered a maximum value. But this process seems to be less important here, because our data do not deviate from a linear trend in the C / V vs. S / V diagram. Furthermore, note that sample preparation of filters was done by scraping off supernatant material (Sect. 2.3), which could have resulted in some kind of sediment fractionation. This in turn could affect the lignin phenol compositions. However, our TSM samples lie within the range of soils and sediments presented here and we suggest this effect to be negligible for the OM source and degradation interpretation below.

Our C / V and S / V values are slightly higher than values measured for particulate and dissolved lignin sampled in the Lena Delta in 1994 (Lobbes et al., 2000) and dissolved lignin sampled from the Lena River at Zhigansk (Amon et al., 2012). This could either be because the contribution of non-woody angiosperm sources, most likely tundra vegetation, to Lena Delta TSM increased since 1994 due to active layer deepening and increased riverbank abrasion. Alternatively, a detectable difference in contribution of non- 

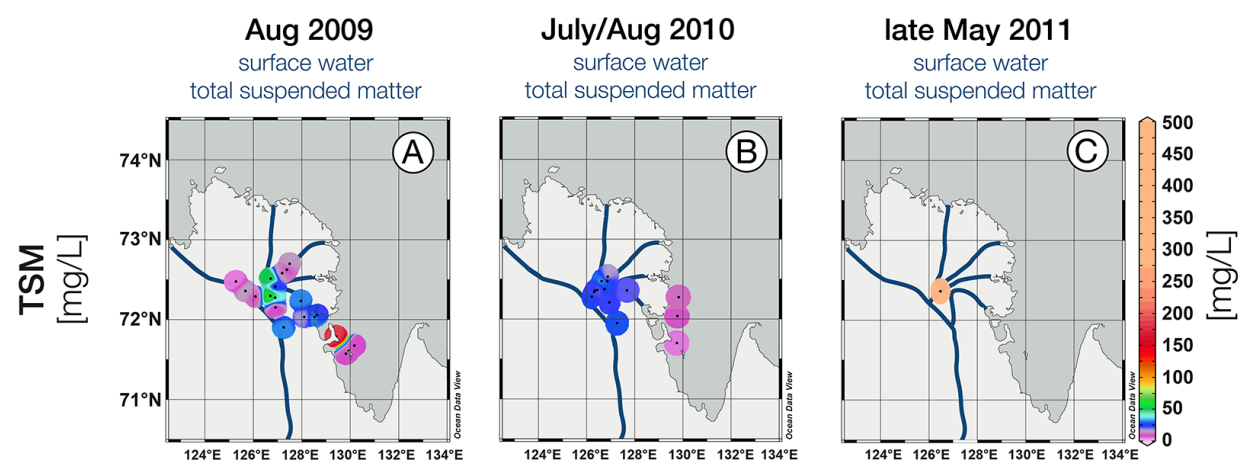

\section{Aug 2010}

Buor Khaya Bay surface sediments
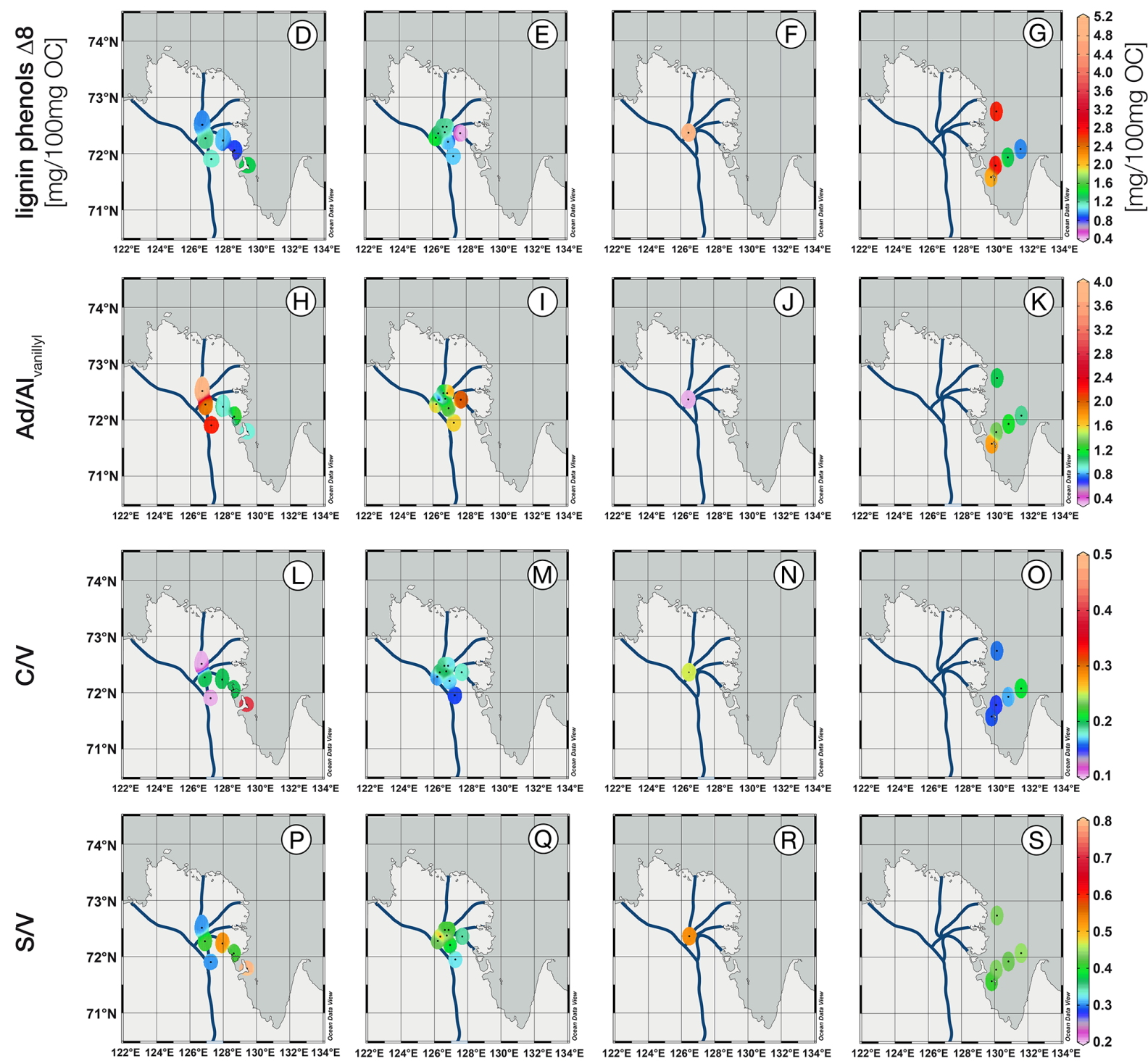

Figure 3. Spatial distribution of carbon-normalized lignin concentrations $(\Lambda 8)$ and lignin parameters of Lena Delta total suspended matter (TSM) and Buor Khaya Bay surface sediments. Ad / $\mathrm{Al}_{\text {vanillyl }}$ : acid to aldehyde ratio of the vanillyl phenols; $\mathrm{C} / \mathrm{V}$ : ratio of cinnamyl to vanillyl phenols; and S / V: ratio of syringyl to vanillyl phenols. 


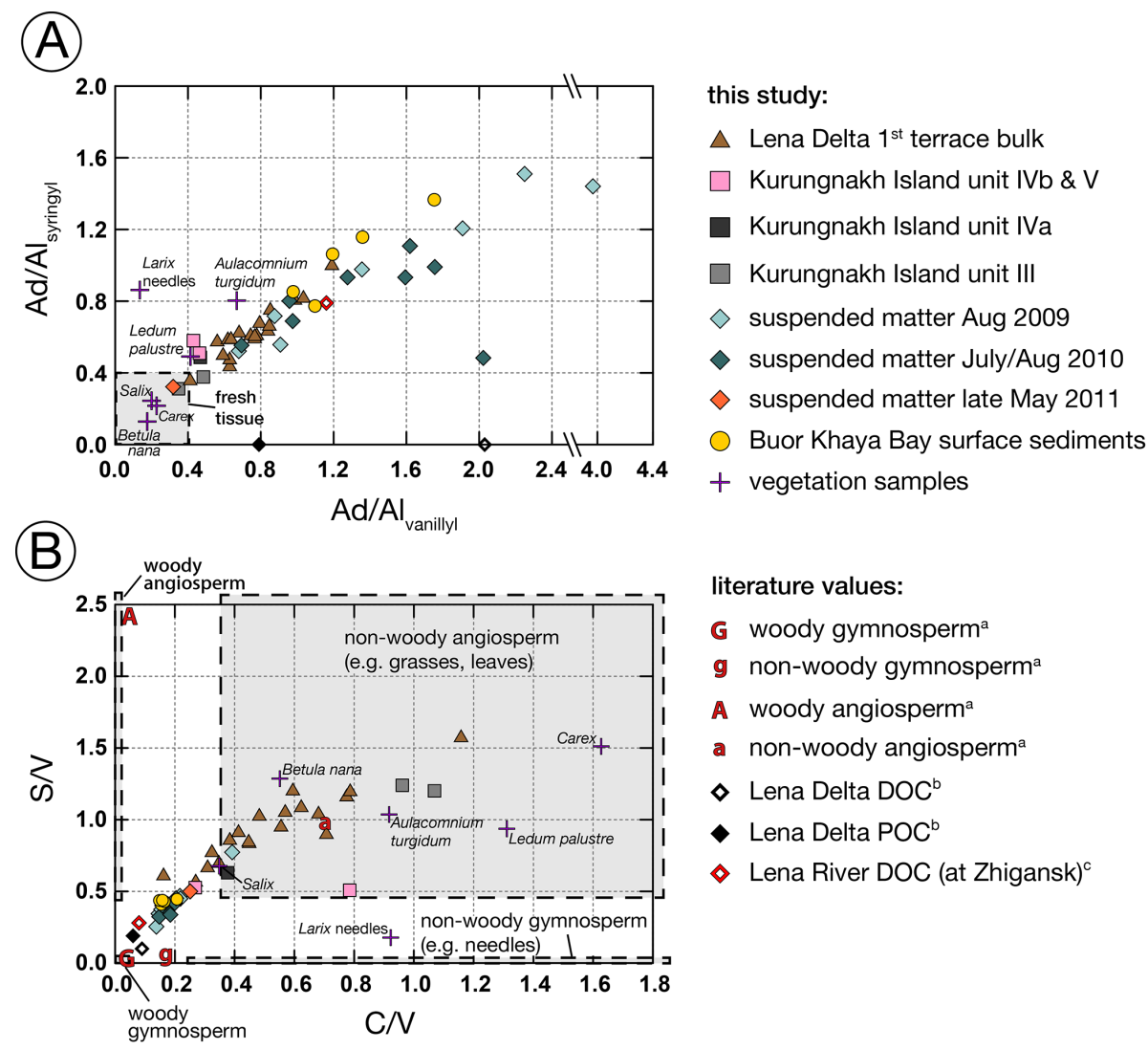

Figure 4. (a) Lignin degradation indices ( $\mathrm{Ad} / \mathrm{Al} \mathrm{V}$ vs. $\left.\mathrm{Ad} / \mathrm{Al}_{\mathrm{S}}\right)$ and (b) vegetation source parameters (C / V vs. S / V) including compositional ranges of major vascular plant types (Goñi et al., 1998; Goñi and Hedges, 1992; Hedges and Mann, 1979; Hu et al., 1999). For abbreviations see Fig. 3. Note the different scales. Literature values: ${ }^{\text {a }}$ end-member values used in this study taken from Table 4 in Amon et al. (2012) and references therein, ${ }^{\mathrm{b}}$ Lobbes et al. (2000), ${ }^{\mathrm{c}}$ Amon et al. (2012). Note that, in (a), there are two values on the Ad / AlV axis where $\mathrm{Ad} / \mathrm{Al}_{\mathrm{S}}$ is zero, because there were no values given in Lobbes et al. (2000).

woody angiosperm OM to delta samples compared to the southern sample location at Zhigansk is simply due to the fact that the latter location lies in the taiga-tundra transition zone, where higher woody gymnosperm contributions would be expected. Thirdly, a large fraction of the particulate river load might be trapped in floodplains and/or the lower reaches of the Lena River. Particularly material from the distal parts of the watershed carrying the predominantly woody gymnosperm signal would not be transported efficiently to the delta. This inefficient transport mechanism of riverine particulate load is characteristic of large river systems and has, for instance, been reported for the Amazon River and the Fly River, Papua New Guinea (e.g., Alin et al., 2008; Aufdenkampe et al., 2007, 2011; Blair and Aller, 2012; Goñi et al., 2014; Moreira-Turcq et al., 2013; Zocatelli et al., 2013). The slightly lower C / V and S / V values from Lobbes et al. (2000) and Amon et al. (2012) could also be well within the range of the natural variability of Lena River TSM composition, which was not covered by samples from 2009 and 2010 in this study. However, it should be noted that dissolved and particulate lignin might be derived from different terrige- nous sources, i.e., from a modern OM pool and a pre-aged OM pool, respectively. In general, dissolved organic matter in Arctic rivers is of modern age, while POM is much older $\left(10^{2}-10^{3}\right.$ years; e.g., Guo and Macdonald, 2006; Guo et al., 2007; Raymond et al., 2007), which could result in differences of the lignin phenol composition and hence be an additional explanation for the differences of C / V and S / V values between our particulate lignin values and the dissolved lignin of Amon et al. (2012). Nonetheless, our C / V and $\mathrm{S} / \mathrm{V}$ ratios clearly depict the catchment vegetation characteristics of the Lena River being a mixture of taiga forest in the south and tundra in the north. They therefore distinguish the Lena River catchment from other Arctic river catchments like the Ob River (Dickens et al., 2011) or Mackenzie River (Goñi et al., 2000).

Although $p$-hydroxybenzenes $(\mathrm{P})$ have multiple sources, the $\mathrm{CuO}$ oxidation of fresh Sphagnum and other mosses, which do not produce the typical lignin phenols, release considerable amounts of $p$-hydroxybenzenes and the $\mathrm{P} / \mathrm{V}$ and $p$-hydroxyacetophenone to $\mathrm{P}$ ratios $(\mathrm{Pn} / \mathrm{P})$ have been used as tracers for Sphagnum-derived OC in peats (Dickens et al., 
2011; Tsutsuki and Kondo, 1995; Williams et al., 1998). The higher P / V ratios of summer TSM from 2009 and 2010 (mean ratios 0.9 and 0.8 , respectively) compared to spring 2011 (0.4; Fig. 5, Table 5) might indicate a higher contribution of mosses to Lena Delta TSM in the summer season, presumably derived from local tundra vegetation. Alternatively, the rather high fraction of phytoplankton-derived OM contributing to our summer samples (see Winterfeld and Mollenhauer, 2014, companion paper) could also result in higher $\mathrm{P} / \mathrm{V}$ ratios, as phytoplankton has been shown to contain elevated amounts of P (e.g., Goñi and Hedges, 1995). Overall, the summer and spring P / V ratios in TSM were lower than the mean bulk $\mathrm{P} / \mathrm{V}$ ratio of the first and third terrace (1.1 and 1.0, respectively), the moss sample (Aulacomnium turgidum) analyzed here (P / V ratio of 2.3), and other values from the literature for Sphagnum moss and peat (see Fig. 5). The relatively lower P / V ratios in TSM samples thus indicate that moss contribution is minor compared to a dominant non-woody angiosperm source, particularly when considering possible $\mathrm{P}$ contributions from phytoplankton to TSM.

\subsubsection{State of diagenetic alteration of suspended particulate lignin biomarkers}

Lignin phenol composition has been widely used to identify sources of terrigenous OM in aquatic and soil systems and characterize the degree of aerobic degradation (e.g., Benner et al., 1990; Goñi and Hedges, 1992; Hedges and Mann, 1979; Hernes and Benner, 2002; Tesi et al., 2007). The acid to aldehyde ratios of vanillyl and syringyl ( $\left.\mathrm{Ad} / \mathrm{Al}_{\mathrm{V}}, \mathrm{S}\right)$ usually increase with increasing OM oxidation. In general, values $<0.4$ for both ratios are considered fresh, and samples with values $>0.4$ have undergone some degree of degradation (Goñi et al., 1993; Hedges et al., 1988).

The TSM Ad / Alv, s ratios vary annually and with the hydrograph. The spring flood value from 2011 appears to be derived mainly from fresh plant litter and/or surface soils (Fig. 4a), in agreement with the dissolved organic matter (DOM) exported during the flood, which was also found to be younger than summer DOM (Amon et al., 2012). In contrast, the $\mathrm{Ad} / \mathrm{Al}_{\mathrm{V}}$, s ratios of our TSM collected in summer indicate a more degraded OM source presumably from deeper soil horizons that thawed during the summer months. The deeper soil OM could partly originate from the first and third delta terraces. However, most of the $\mathrm{Ad} / \mathrm{Al}$, s ratios we determined for the TSM were higher than the bulk soil $\mathrm{Ad} / \mathrm{Al}$, s ratios of the first and third terraces. Such a finding points to either an additional, more degraded source, most likely from south of the Lena Delta, or a more degraded fraction of soil present in suspended matter, most likely the fine fraction. The fine grain-size fraction of soils and riverine suspended matter are generally associated with higher Ad / Alv, s ratios (Carrington et al., 2012; Guggenberger et al., 1994; Hedges et al., 1986) and the fine fraction is also most likely to be held in suspension during lower sum- mer flows compared to coarser grain sizes. Terrigenous OM that is similarly degraded was also found in the surface waters of the Mackenzie River delta, which also drains from a permafrost-affected watershed (Goñi et al., 2000).

Additionally, sorption of dissolved lignin to mineral surfaces could have an effect on the Ad / AlV, s ratios. Dissolved lignin in the Lena River has high Ad / Alv, S ratios of $\sim 0.9$ to 1.6 during the peak flow and $\sim 0.6$ to 1.3 during mid- and base flow (Amon et al., 2012). Higher Ad / Alv, S ratios of dissolved lignin are not necessarily associated with highly degraded lignin, as they are also observed when dissolved lignin is derived from leaching of litter or soil (Hernes et al., 2007). The Lena Delta summer TSM ratios from 2009 and 2010 were higher than any other values reported for particulate lignin in the Lena Delta or other Arctic rivers (Dickens et al., 2011; Goñi et al., 2000; Lobbes et al., 2000), and in large part also higher than values in dissolved lignin. Thus, they cannot be explained by sorption of dissolved lignin but potentially reflect input from a highly degraded source, e.g., from greater soil depths of the southern catchment.

\subsection{Spatial patterns in Buor Khaya Bay surface sediments}

\subsubsection{Lignin biomarker abundances}

In contrast to the surface water TSM snapshots, the surface sediments from Buor Khaya Bay integrate the sedimentary $\mathrm{OM}$ and associated lignin phenol signal over a certain period of time depending on the local accumulation rates and the sediment re-working by waves and land-fast ice affecting the shallow coastal zone. The surface sediments therefore reflect an average of the OM transported to the coastal zone and smooth the seasonal and interannual differences in $\mathrm{OM}$ properties as well as the differences between OM sources. Buor Khaya Bay sedimentary OM is mainly derived from three sources, i.e., terrigenous OM transported by the Lena River, terrigenous OM derived from coastal erosion of the Buor Khaya coast predominantly consisting of Pleistocene ice complex deposits, and aquatic (riverine and marine) primary production. The latter source is negligible when discussing lignin phenols.

The sediment-normalized $(\Sigma 8)$ and carbon-normalized $(\Lambda 8)$ lignin phenol concentrations of Buor Khaya Bay surface sediments are high in front of the two main delta outlets, the Sardakh-Trofimovskaya channel and the Bykovskaya channel (Fig. 3g, Tables 4 and 5), and decrease offshore. This points to the Lena River as the dominant source of lignin phenols with decreasing influence offshore, presumably as a result of hydrodynamic sorting where a less lignin phenolrich finer sediment fraction is transported further offshore. Highest $\Sigma 8$ contributions from coastal erosion are evident at the site off Muostakh Island (L09-34), while the carbonnormalized yield $(\Lambda 8)$ at this location was slightly smaller than at the river outlets (samples L10-23 and L10-36). 

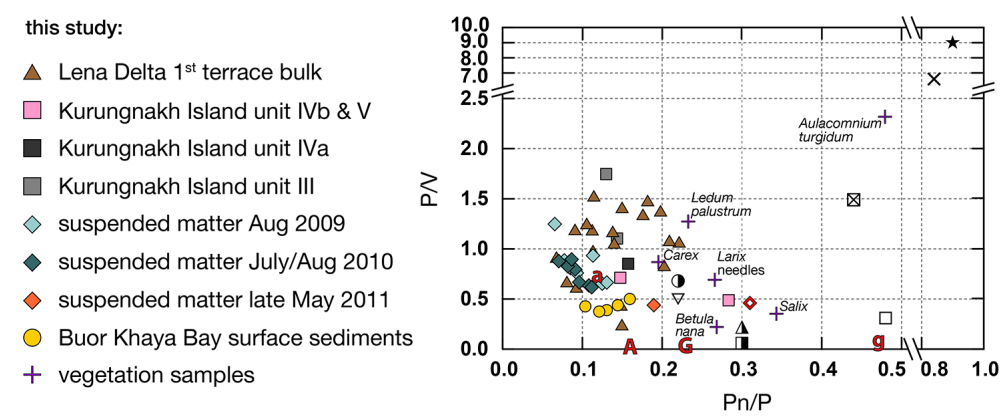

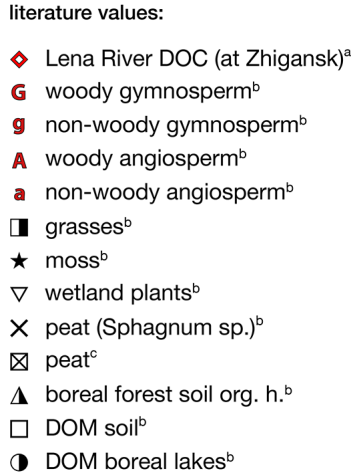

Figure 5. The ratios of $p$-hydroxyacetophenone to $p$-hydroxybenzenes (Pn / P) vs. $p$-hydroxybenzenes to vanillyl phenols (P / V) of samples analyzed in this study and values from the literature used as an indicator of moss contributions. ${ }^{a}$ Amon et al. (2012), ${ }^{\mathrm{b}}$ Table 4 in Amon et al. (2012) and references therein, ${ }^{\mathrm{c}}$ Williams et al. (1998).

High lignin phenol concentrations are generally associated with the coarse particulate OM fraction in soils and suspended material and they decrease with decreasing grain size (Carrington et al., 2012; Guggenberger et al., 1994; Hedges et al., 1986). An offshore gradient of decreasing grain size off the delta coast and towards greater water depths has been reported for Buor Khaya Bay (Charkin et al., 2011). The spring flood could play a major role in transporting coarser ligninbearing $\mathrm{OM}$ to the coastal zone, which is in agreement with the high spring flood $\Sigma 8$ and $\Lambda 8$ concentrations from 2011. In contrast, slower current velocities during summer would transport fine particulate material to the delta edge or further offshore, carrying a lower $\Lambda 8$ signature. Alternatively, the increased sedimentation of particulate and dissolved material through flocculation in the mixing zone of fresh and salt water in the prodelta area (marginal filter; cf. Lisitsyn, 1995) could be an additional reason for increased lignin phenol concentrations at these sample locations. Unfortunately, there is not much known about transport of sediment along the delta channels to the coastal zone.

\subsubsection{Vegetation sources contributing to sedimentary organic matter}

We observed a generally high contribution of terrestrial organic matter to the Buor Khaya Bay sediments based on the OC: TN ratios (Table 3). An offshore trend of decreasing OC: TN ratios likely reflects the increasing marine contributions by plankton as well as decreasing amounts of terrigenous material reaching offshore locations, which supports similar findings on OM sources in Buor Khaya Bay surface sediments (e.g., Karlsson et al., 2011; Tesi et al., 2014).

The contribution of woody and non-woody gymnosperm and angiosperm tissues based on $\mathrm{C} / \mathrm{V}$ and $\mathrm{S} / \mathrm{V}$ ratios as well as the contribution from mosses based on the P / V ratios was rather similar for all surface sediment samples. The $\mathrm{C} / \mathrm{V}$ and S / V ratios were notably lower than in the delta soil samples in this study (Figs. 31-s and 4b) and the surface soil and ice complex samples taken in the Lena watershed and along the Buor Khaya coast by Tesi et al. (2014). This suggests a considerable contribution of woody gymnosperm tissues from the southern Lena catchment to Buor Khaya Bay sediments. Additional angiosperm-derived OM contributed by coastal erosion of Pleistocene ice complex deposits (Tesi et al., 2014) seems to dilute the gymnosperm signal from the Lena River with distance to the delta (slight increase in C / V and $\mathrm{S} / \mathrm{V}$ ratios offshore, Table 5). The angiosperm-derived OM originating from the Lena catchment and from coastal erosion of ice complex, respectively, contribute to the Buor Khaya Bay sediments, and these two sources cannot unambiguously be distinguished based on their C / V and S / V ratios. Here, the use of bulk as well as lignin-specific ${ }^{14} \mathrm{C}$ concentrations might be helpful as the Pleistocene ice complex deposits are more depleted in ${ }^{14} \mathrm{C}$ than the soil-derived $\mathrm{OM}$ from the Lena catchment (e.g., Karlsson et al., 2011; Vonk et al., 2012; Winterfeld and Mollenhauer, 2014, companion paper).

Further, sedimentary $\mathrm{P} / \mathrm{V}$ ratios $(0.4$ to 0.5$)$ suggest the fraction of moss-derived OM in the sediments is smaller than in the summer TSM samples (0.62 to 1.25) and bulk soils from the first and third delta terrace (Fig. 5, Table 5). Instead, the sedimentary $\mathrm{P} / \mathrm{V}$ ratios were similar to the spring TSM sample from 2011 (value of 0.4), pointing to a considerable contribution of spring flood TSM to Buor Khaya Bay sediments. However, we cannot exclude that lower P/V ratios could be partially the result of selective degradation of more labile $\mathrm{P}$ phenols compared to $\mathrm{V}$ phenols resulting in lower $\mathrm{P} / \mathrm{V}$ ratios than carried by the original $\mathrm{OM}$ source (Hedges and Weliky, 1989; Williams et al., 1998). Moreover, as discussed above for the TSM samples, we also cannot exclude possible contributions from phytoplankton containing elevated $\mathrm{P}$ concentrations to sedimentary $\mathrm{OM}$. The slight increase in $\mathrm{P} / \mathrm{V}$ ratios further offshore (samples L10-23 to L10-25, Table 5) might point to higher phytoplankton OM contributions with larger distance to the coast. The estimated 
relative contributions of the different vegetation zones in the Lena catchment will be discussed in Sect. 4.3.1.

\subsubsection{Degradation of terrigenous organic matter}

The relatively high Ad / Alv, s ratios (0.77 to 1.75; Table 5, Fig. 3k) imply a rather strong degradation of lignin phenols in the surface sediments. There is a small gradient towards less degraded material along the offshore transect (Fig. 3k) of progressively finer sediments (Charkin et al., 2011). This is in contrast to analysis of soils and Amazon River suspended material, where $\mathrm{Ad} / \mathrm{Al}_{\mathrm{V}, \mathrm{S}}$ ratios increased with decreasing particle size (Amelung et al., 1999; Carrington et al., 2012; Hedges et al., 1986). As summer TSM in our samples is predominantly strongly degraded (see Sect. 4.1) and, as discussed above, is inferred to be more fine-grained than the less degraded spring flood material, this observation creates an argument against a dominant control of hydrodynamic sorting on the lignin monomer distribution. An additional OM source with a less degraded $\mathrm{Ad} / \mathrm{Al}_{\mathrm{V}}$, s signature contributing to Buor Khaya Bay sediments, e.g., Lena River spring flood TSM or material derived from erosion of ice complex deposits along the Buor Khaya coast, could explain the offset. Efficient sediment redistributing processes such as bottom erosion and nepheloid layer bottom transport of sediments in Buor Khaya Bay have been identified by Charkin et al. (2011).

It is difficult to assess where the lignin degradation occurred. Oxidative degradation of the lignin macromolecule in soils by fungi is known to increase $\mathrm{Ad} / \mathrm{Al}_{\mathrm{V}, \mathrm{S}}$ ratios greatly (e.g., Goñi et al., 1993). Subaqueous decay of lignin has also been shown to increase the $\mathrm{Ad} / \mathrm{Al}$ ratios (e.g., Opsahl and Benner, 1995). We favor the explanation of aerobic degradation on land, because $\mathrm{Ad} / \mathrm{Al}_{\mathrm{V}, \mathrm{s}}$ ratios of the sediment samples are in the upper range of values found in the bulk first terrace soils and well within the range of summer TSM samples from the delta, suggesting that river-transported material is the dominant source of OM deposited in surface sediments. The one spring flood sample from 2011 appears to be relatively fresh. If the majority of particle discharge to the Laptev Sea occurs during spring, we would expect that similarly low $\mathrm{Ad} / \mathrm{Al}$, $\mathrm{S}$ ratios would be observed in the sediments. The fact that we do not observe such a signal might be either due to insufficient information about the heterogeneity of material transported during the spring flood or due to efficient degradation of lignin during transport and/or early diagenesis. Karlsson et al. (2011) studied bulk parameters and lipid biomarker contents of surface sediments in Buor Khaya Bay. Using a three-EM and dual-isotope $\left(\delta^{13} \mathrm{C}\right.$ and $\left.\Delta^{14} \mathrm{C}\right)$ Monte Carlo simulation, these authors suggested that about $60 \%$ of the sedimentary OM is derived from ice complex deposits and roughly $20 \%$ each from surface soils and primary production. Further, using lipid biomarker indicators for OM degradation and ${ }^{14} \mathrm{C}$ dating, they found marked differences between river-derived POC that was younger and more degraded and sedimentary OM that was older but less degraded. These lipid-based findings are in contrast to our lignin data, which suggest similar states of degradation for both river-derived OM and surface sediments.

Notably, the highest $\mathrm{Ad} / \mathrm{Al} \mathrm{V}$ ratio of 1.75 was measured offshore of Muostakh Island (Fig. 3k, Table 5), which consists of Pleistocene ice complex deposits. In contrast, the $\mathrm{Ad} / \mathrm{Al}$ V ratios of ice complex deposits on Muostakh Island were much lower, varying between 0.16 and 0.95 (see Tesi et al., 2014). Additionally, other ice complex deposits from the Buor Khaya Cape and along the Lena channel (Tesi et al., 2014) as well as from Kurungnakh (this study) showed similarly low $\mathrm{Ad} / \mathrm{Al} \mathrm{V}_{\mathrm{V}}$ ratios, supporting the idea of relatively fresh ice complex OM (e.g., Karlsson et al., 2011; Vonk et al., 2012). Therefore, the lignin fraction of the OM must have been strongly degraded between erosion and deposition in surface sediments. This could have happened after thawing on land and/or post-depositionally under subaqueous conditions. Vonk et al. (2012) suggested that substantial degradation of Muostakh Island ice complex material occurs rapidly and immediately after thawing. Sanchez-García et al. (2011) determined rapid particulate OM degradation rates to occur subaqueously in shallow Laptev Sea waters.

\subsection{Terrigenous organic matter sources of Lena Delta suspended matter and Buor Khaya Bay surface sediments}

\subsubsection{Unmixing of taiga and tundra vegetation contributions}

As, in a first approximation, gymnosperm vegetation is restricted exclusively to the taiga part of the Lena River catchment, we use the gymnosperm to angiosperm ratio as an estimate of the relative contributions of taiga and tundra. Therefore, we combined the model solutions for woody and nonwoody contributions of gymnosperms and angiosperms, respectively. According to the model presented here, the fractions of gymnosperm and angiosperm-derived OM varied strongly in the summer TSM samples. However, the mean gymnosperm contributions for spring 2011 and the summers 2009 and 2010 were very similar (Table 7), i.e., $0.4(n=1)$, $0.5(n=7)$, and $0.6(n=8)$, respectively. The Buor Khaya Bay surface sediment total gymnosperm fraction was in the range of the TSM values (mean fraction $=0.5, n=5$ ). In summary, the model suggests roughly equal contributions of total gymnosperm and total angiosperm-derived OM in suspended particulate $\mathrm{OM}$ and sediments based on the lignin monomer distribution. This implies that a large fraction of the gymnosperm POM derived from the taiga gets trapped in floodplains along the course of the Lena River, and hence the contribution of angiosperm vegetation, mainly present in the tundra, to surface water TSM is relatively big. The Buor Khaya Bay surface sediments receive additional angiospermderived OM through coastal erosion of ice complex deposits 
(Tesi et al., 2014), which adds to the angiosperm-derived OM from the Lena catchment and dilutes the gymnosperm signal with distance to the delta. Moreover, we cannot distinguish, and therefore not exclude, small angiosperm contributions from the taiga zone itself, being a heterogeneous landscape with some amount of angiosperm vegetation and contributions from higher elevated areas, where bushes and grasslands are favored over trees. Thus, taiga-derived material might indeed account for more than $50 \%$ of the total lignin in our samples, which in turn implies that, based on our model, the maximum contribution by the tundra zone (angiosperm $\mathrm{OM}$ ) is $50 \%$. Also, the $\mathrm{C} / \mathrm{V}$ and $\mathrm{S} / \mathrm{V}$ values we chose for the non-woody angiosperm source ("a" in Fig. 4b; see Hedges and Parker, 1976; Hedges and Mann, 1979) add some uncertainty to the model results that has to be considered when interpreting the data. As shown in Fig. 4b, the end-member values lie well within most of the soil samples, but there are also several soil and vegetation samples with higher and lower C / V and S / V ratios. Using more representative end-member values including the natural variability of the different permafrost soil sources could reduce the model uncertainty here. Unfortunately, this kind of data is not yet available for the Lena watershed.

The comparison of $\mathrm{C} / \mathrm{V}$ and $\mathrm{S} / \mathrm{V}$ ratios between dissolved and particulate lignin can be complicated by fractionation processes occurring during leaching of lignin phenols from plant tissues and soils as well as sorption of dissolved lignin to minerals in soils or sediments (Hernes et al., 2007). However, Lobbes et al. (2000) and Amon et al. (2012) have shown that C / V and S / V ratios of dissolved lignin in Arctic rivers, including the Lena River, reflect the vegetation signal of the individual catchments and are not significantly altered by degradation or fractionation. Therefore, we feel confident in comparing our Lena Delta data with C / V and S / V ratios generated by Amon et al. (2012).

We compared the gymnosperm fractions in our samples with the results from Amon et al. (2012), who estimated a total gymnosperm contribution of $70 \%$ to Lena River dissolved lignin. Despite a broad range of ratios in our summer TSM and surface sediments, we infer a substantially lower gymnosperm contribution to particulate $\mathrm{OM}$ in the delta surface water and Buor Khaya Bay surface sediments than further upstream at Zhigansk. This finding clearly indicates the overprint of TSM signatures by higher contributions of angiosperm OM contributing to the total TSM load between Zhigansk, located at the taiga-tundra transition zone, and our sampling sites in the delta. As mentioned above, this might be due to the inefficient transport of POM from distal catchment areas to the delta and its intermediate storage on floodplains (e.g., Aufdenkampe et al., 2007; 2011; Moreira-Turcq et al., 2013; Zocatelli et al., 2013). In contrast, dissolved organic matter including dissolved lignin is transported with the flow of the water, which might lead to a more efficient transport of taiga-derived DOM to the delta, thus explaining the difference in modeled gymnosperm contributions in
Amon et al. (2012) and our study. The resulting considerable impact of the northern part of the catchment area to the POM composition is disproportional to its small spatial extent within the Lena River drainage area. It further implies environmental changes associated with above average climate warming expected for the high northern latitudes will most likely increase the disproportional OM input by enhanced permafrost thawing in the north compared to the southern catchment.

\section{Conclusions}

Despite the annual, seasonal, and spatial variability, the distribution of lignin phenols in our Lena delta surface water TSM samples clearly reflects the main vegetation characteristics of the Lena River catchment. The gymnosperm fraction derived from the taiga covering most of the catchment and the angiosperm fraction derived predominantly from the northern tundra zone contribute about equally to the spring and summer TSM samples. However, because of possible contributions of angiosperm OM from the taiga zone, for example from elevated treeless areas, the $50 \%$ angiosperm vegetation have to be interpreted as the maximum contribution from tundra zone. Considering the relatively small area covered by tundra ( 12\%; e.g., Amon et al., 2012$)$ this still relatively high angiosperm contribution emphasizes the importance of this small area as organic matter source to the Lena Delta surface water TSM and Laptev Sea coastal zone, where it adds to the angiosperm OM contributed by coastal erosion.

Based on the low acid to aldehyde ratios of vanillyl and syringyl phenols ( $\mathrm{Ad} / \mathrm{Al}_{\mathrm{V}}, \mathrm{s}$ ), the spring flood sample seems to have organic matter that has undergone a relatively low extent of degradation and most likely originates from surface soils and fresh vegetation. This could be due to the fact that, particularly in the northern part of the catchment, the soils are still frozen at the time of the spring freshet, which may favor surface erosion by the flood wave. On the other hand, less degraded $\mathrm{OM}$ with low $\mathrm{Ad} / \mathrm{Al}_{\mathrm{V}}$, ratios is also found in ice complex deposits of Pleistocene age (e.g., Tesi et al., 2014) and does not necessarily have to be derived from surface soils. The summer TSM samples displayed compositions ( $\mathrm{Ad} / \mathrm{Al} \mathrm{V}, \mathrm{s})$ consistent with higher degrees of degradation, and presumably originated from greater soil depths thawed during the summer months. As the first and third delta terrace bulk soil samples analyzed here had generally lower $\mathrm{Ad} / \mathrm{Al}$, S ratios than the summer TSM, we speculate that there must be an additional more degraded organic matter source. This source could be organic matter derived from the southern catchment, where annual permafrost thaw depths are greater than in the Lena Delta. Because these materials are transported to the delta during lower flow conditions, it is likely they are predominantly composed of finer particles, which usually contain more highly altered lignin and may 
have been affected by sorptive processes with DOM, all of which can contribute to the higher $\mathrm{Ad} / \mathrm{Al}$, s ratios.

The marginal filter leading to flocculation of dissolved and particulate organic matter and rapid sedimentation seems to be the dominant reason for high lignin contents off the major delta outlets. Similar to the TSM samples, the lignin distribution within the surface sediments of Buor Khaya Bay points to a mixed gymnosperm and angiosperm vegetation source of organic matter, and the modeled contributions are also about equal for both sources. The additional contribution of angiosperm-derived OM to Buor Khaya Bay sediments through coastal erosion makes it difficult to unambiguously distinguish between angiosperm-derived OM from the Lena watershed and from coastal erosion of ice complex deposits. However, as gymnosperm vegetation is not present in the Lena Delta and along the Buor Khaya coast today and their respective Holocene and Pleistocene deposits but covers the southern part of the Lena River catchment, the fact that we find gymnosperm-derived OM in surface sediments suggests that a substantial amount of sedimentary organic matter in Buor Khaya Bay originates from the Lena River catchment. The additional source of angiosperm OM contributed by coastal erosion results in dilution of the gymnosperm signal with distance to the delta.

The surface sediments were strongly degraded, resembling the Lena Delta summer samples and implying that at least some summer TSM is transported from the delta to the coastal zone. However, the strong degradation of sedimentary organic matter close to Muostakh Island consisting of Pleistocene ice complex and being affected by coastal erosion, which most likely happened after thawing on land, makes it complicated to distinguish between degraded ice complex and degraded summer TSM-derived organic matter.

In the future, more severe warming is expected for the high northern latitudes (IPCC, 2013), which will presumably influence the northernmost part of the Lena River catchment, i.e., the tundra zone with the delta, more strongly than the southern part. On the basis of our data it should be possible to trace changes in OM contribution and quality from different parts of the Lena River catchment area. Additionally, more research is needed to investigate the fate of Lena River and ice complex organic matter, particularly their degradability on land, in the water column, and post-depositionally, in order to understand their potential for possible increase in greenhouse gas release from the Arctic.

Additional data on individual $\mathrm{CuO}$ oxidation products for the samples presented here can be found in PANGAEA (www.pangaea.de).

The Supplement related to this article is available online at doi:10.5194/bg-12-2261-2015-supplement.
Acknowledgements. The Helmholtz Young Investigators program of the Helmholtz Society (GM), the Alfred Wegener Institute, and a fellowship from the German Academic Exchange Service (DAAD) to M. Winterfeld supported this study. We thank Waldemar Schneider from the Alfred Wegener Institute, Potsdam, Germany, and our Russian partners from the Tiksi Hydrobase, Lena Delta Reserve, and the Arctic and Antarctic Institute, St. Petersburg, Russian Federation, for logistical support in preparation and during the expeditions. We acknowledge the good collaboration with the crews of the vessels Puteyski 405 and PTS during fieldwork in 2009 and 2010 and the help and good company of all participants of the LENA DELTA expeditions 2009-2011. We thank Ralph Kreutz for taking samples in spring 2011. Lignin laboratory analysis was greatly supported and guided by Yvan Alleau (Oregon State University, Corvallis, USA). We thank Sebastian Wetterich and Lutz Schirrmeister (AWI Potsdam, Germany) for providing sediment samples from Kurungnakh Island and Ulrike Herzschuh, Juliane Klemm, and Romy Zibulski (AWI Potsdam, Germany) for identifying and providing vegetation samples from the Lena River catchment. We further thank Katja Hockun for assistance with processing the vegetation samples. Finally, we thank T. Tesi and the anonymous reviewer for their constructive comments.

Edited by: N. Ohkouchi

\section{References}

Aitchison, J.: The statistical analysis of compositional data, J. R. Stat. Soc. B, 44, 139-177, 1982.

Alin, S., Aalto, R., Goñi, M., Richey, J., and Dietrich, W.: Biogeochemical characterization of carbon sources in the Strickland and Fly rivers, Papua New Guinea, J. Geophys. Res., 113, F01S05, doi:10.1029/2006JF000625, 2008.

Alling, V., Porcelli, D., Mörth, C. M., Anderson, L. G., SanchézGarcía, L., Gustafsson, Ö., Andersson, P. S., and Humborg, C.: Degradation of terrestrial organic carbon, primary production and out-gassing of $\mathrm{CO}_{2}$, Geochim. Cosmochim. Ac., 95, 143159, doi:10.1016/j.gca.2012.07.028, 2012.

Amelung, W., Flach, K.-W., and Zech, W.: Lignin in particle-size fractions of native grassland soils as influenced by climate, Soil Sci. Soc. Am. J., 63, 1222-1228, 1999.

Amon, R. M. W., Rinehart, A. J., Duan, S., Louchouarn, P., Prokushkin, A., Guggenberger, G., Bauch, D., Stedmon, C., Raymond, P. A., Holmes, R. M., McClelland, J. W., Peterson, B. J., Walker, S. A., and Zhulidov, A. V.: Dissolved organic matter sources in large Arctic rivers, Geochim. Cosmochim. Ac., 94, 217-237, doi:10.1016/j.gca.2012.07.015, 2012.

A-GRO: Arctic Great Rivers Observatory, version 1.4, last updated 17 July 2012, available at: www.arcticgreatrivers.org, last access 14 February, 2014.

Aufdenkampe, A. K., Mayorga, E., Hedges, J. I., Llerena, C., Quay, P. D., Gudeman, J., Krusche, A. V., and Richey, J. E.: Organic matter in the Peruvian headwaters of the Amazon: Compositional evolution from the Andes to the lowland Amazon mainstem, Org. Geochem., 38, 337-364, doi:10.1016/j.orggeochem.2006.06.003, 2007.

Aufdenkampe, A. K., Mayorga, E., Raymond, P. A., Melack, J. M., Doney, S. C., Alin, S. R., Aalto, R. E., and Yoo, K.: Riverine 
coupling of biogeochemical cycles between land, oceans, and atmosphere, Front. Ecol. Environ., 9, 53-60, doi:10.1890/100014, 2011.

Benner, R., Weliky, K., and Hedges, J. I.: Early Diagenesis of Mangrove Leaves in a Tropical Estuary - Molecular-Level Analyses of Neutral Sugars and Lignin-Derived Phenols, Geochim. Cosmochim. Ac., 54, 1991-2001, 1990.

Bianchi, T., Wysocki, L., Stewart, M., Filley, T., and McKee, B.: Temporal variability in terrestrially-derived sources of particulate organic carbon in the lower Mississippi River and its upper tributaries, Geochim. Cosmochim. Ac., 71, 4425-4437, doi:10.1016/j.gca.2007.07.011, 2007.

Blair, N. and Aller, R.: The Fate of Terrestrial Organic Carbon in the Marine Environment, Annu. Rev. Mar. Sci., 4, 401-423, doi:10.1146/annurev-marine-120709-142717, 2012.

Boike, J., Kattenstroth, B., Abramova, K., Bornemann, N., Chetverova, A., Fedorova, I., Fröb, K., Grigoriev, M., Grüber, M., Kutzbach, L., Langer, M., Minke, M., Muster, S., Piel, K., Pfeiffer, E.-M., Stoof, G., Westermann, S., Wischnewski, K., Wille, C., and Hubberten, H.-W.: Baseline characteristics of climate, permafrost and land cover from a new permafrost observatory in the Lena River Delta, Siberia (1998-2011), Biogeosciences, 10, 2105-2128, doi:10.5194/bg-10-2105-2013, 2013.

Carrington, E., Hernes, P., Dyda, R., Plante, A., and Six, J.: Biochemical changes across a carbon saturation gradient: Lignin, cutin, and suberin decomposition and stabilization in fractionated carbon pools, Soil Biol. Biochem., 47, 179-190, doi:10.1016/j.soilbio.2011.12.024, 2012.

Cauwet, G. and Sidorov, I.: The biogeochemistry of Lena River: organic carbon and nutrients distribution, Mar. Chem., 53, 211227, 1996.

CAVM Team: Circumpolar Arctic Vegetation Map (1:7500000 scale), Conservation of Arctic Flora and Fauna (CAFF) Map No. 1., U.S. Fish and Wildlife Service, Anchorage, Alaska, 2003.

Charkin, A. N., Dudarev, O. V., Semiletov, I. P., Kruhmalev, A. V., ] Vonk, J. E., Sánchez-García, L., Karlsson, E., and Gustafsson, Ö.: Seasonal and interannual variability of sedimentation and organic matter distribution in the Buor-Khaya Gulf: the primary recipient of input from Lena River and coastal erosion in the southeast Laptev Sea, Biogeosciences, 8, 2581-2594, doi:10.5194/bg8-2581-2011, 2011.

Dickens, A. F., Baldock, J., Kenna, T. C., and Eglinton, T. I.: A depositional history of particulate organic carbon in a floodplain lake from the lower Ob' River, Siberia, Geochim. Cosmochim. Ac., 75, 4796-4815, doi:10.1016/j.gca.2011.05.032, 2011.

Drenzek, N. J., Montluçon, D. B., Yunker, M. B., Macdonald, R. W. ,and Eglinton, T. I.: Constraints on the origin of sedimentary organic carbon in the Beaufort Sea from coupled molecular ${ }^{13} \mathrm{C}$ and ${ }^{14} \mathrm{C}$ measurements, Mar. Chem., 103, 146-162, doi:10.1016/j.marchem.2006.06.017, 2007.

Fedorova, I., Chetverova, A., Bolshiyanov, D., Makarov, A., Boike, J., Heim, B., Morgenstern, A., Overduin, P. P., Wegner, C., Kashina, V., Eulenburg, A., Dobrotina, E., and Sidorina, I.: Lena Delta hydrology and geochemistry: long-term hydrological data and recent field observations, Biogeosciences, 12, 345-363, doi:10.5194/bg-12-345-2015, 2015.

Feng, X., Simpson, A., Wilson, K., Dudley Williams, D., and Simpson, M.: Increased cuticular carbon sequestration and lignin ox- idation in response to soil warming, Nat. Geosci., 1, 836-839, doi:10.1038/ngeo361, 2008.

Feng, X., Vonk, J. E., van Dongen, B. E., Gustafsson, Ö., Semiletov, I. P., Dudarev, O. V., Wang, Z., Montluçon, D. B., Wacker, L., and Eglinton, T. I.: Differential mobilization of terrestrial carbon pools in Eurasian Arctic river basins, P. Natl. Acad. Sci. USA, 110, 14168-14173, doi:10.1073/pnas.1307031110, 2013.

Galimov, E. M., Kodina, L. A., Stepanets, O. V., and Korobeinik, G. S.: Biogeochemistry of the Russian Arctic. Research Results under the SIRRO Project, 1995-2003, Geochem. Int., 44, 10531104, 2006.

Goñi, M. and Hedges, J.: Lignin dimers: Structures, distribution, and potential geochemical applications, Geochim. Cosmochim. Ac., 56, 4025-4043, 1992.

Goñi, M. and Hedges, J.: Sources and reactivities of marine-derived organic matter in coastal sediments as determined by alkaline $\mathrm{CuO}$ oxidation, Geochim. Cosmochim. Ac., 59, 2965-2981, 1995.

Goñi, M. and Montgomery, S.: Alkaline $\mathrm{CuO}$ Oxidation with a Microwave Digestion System: Lignin Analyses of Geochemical Samples, Anal. Chem., 72, 3116-3121, doi:10.1021/ac991316w, 2000.

Goñi, M., Nelson, B., Blanchette, R., and Hedges, J.: Fungal degradation of wood lignins: geochemical perspectives from $\mathrm{CuO}-$ derived phenolic dimers and monomers, Geochim. Cosmochim. Ac., 57, 3985-4002, 1993.

Goñi, M., Ruttenberg, K. C., and Eglinton, T. I.: A reassessment of the source and importance of land-derived organic matter in surface sediments from the Gulf of Mexico, Geochim. Cosmochim. Ac., 62, 3055-3075, 1998.

Goñi, M., Yunker, M., Macdonald, R., and Eglinton, T.: Distribution and sources of organic biomarkers in arctic sediments from the Mackenzie River and Beaufort Shelf, Mar. Chem., 71, 23-51, 2000.

Goñi, M., Teixeira, M., and Perkey, D.: Sources and distribution of organic matter in a river-dominated estuary (Winyah Bay, SC, USA), Estuar. Coast. Shelf S., 57, 1023-1048, doi:10.1016/S0272-7714(03)00008-8, 2003.

Goñi, M., Aceves, H., Benitez-Nelson, B., Tappa, E., Thunell, R., Black, D., Muller-Karger, F., Astor, Y., and Varela, R.: Oceanographic and climatologic controls on the compositions and fluxes of biogenic materials in the water column and sediments of the Cariaco Basin over the Late Holocene, Deep-Sea Res. Pt. I, 56, 614-640, doi:10.1016/j.dsr.2008.11.010, 2009.

Goñi, M., O’Connor, A. E., Kuzyk, Z. Z., Yunker, M. B., Gobeil, C., and Macdonald, R. W.: Distribution and sources of organic matter in surface marine sediments across the North American Arctic margin, J. Geophys. Res., 118, 4017-4035, doi:10.1002/jgrc.20286, 2013.

Goñi, M., Moore, E., Kurtz, A., Portier, E., Alleau, Y., and Merrell, D.: Organic matter compositions and loadings in soils and sediments along the Fly River, Papua New Guinea, Geochim. Cosmochim. Ac., 140, 275-296, doi:10.1016/j.gca.2014.05.034, 2014.

Grigoriev, M.: Cryomorphogenesis in the Lena Delta, Permafrost Institute Press, Yakutsk, Russia, 176 pp., 1993.

Guggenberger, G., Christensen, B. T., and Zech, W.: Land-use effects on the composition of organic matter in particle-size sep- 
arates of soil: I. Lignin and carbohydrate signature, Eu. J. Soil Sci., 45, 449-458, 1994.

Günther, F., Overduin, P. P., Sandakov, A. V., Grosse, G., and Grigoriev, M. N.: Short- and long-term thermo-erosion of ice-rich permafrost c oasts in the Laptev Sea region, Biogeosciences, 10, 4297-4318, doi:10.5194/bg-10-4297-2013, 2013.

Guo, L. and Macdonald, R. W.: Source and transport of terrigenous organic matter in the upper Yuko River: Evidence from isotope $\left(\delta^{13} \mathrm{C}, \Delta^{14} \mathrm{C}\right.$, and $\left.\delta^{15} \mathrm{~N}\right)$ composition of dissolved, olloidal, and particulate phases, Global Biochem. Cy., 20, GB2011, doi:10.1029/2005GB002593, 2006.

Guo, L., Semiletov, I., Gustafsson, Ö., Ingri, J., Semi, Andersson, P., Dudarev, O., Gust, and White, D.: Characterization of Siberian Arctic coastal sediments: Implications for terrestrial organic carbon export, Global Biogeochem. Cy., 18, GB1036, doi:10.1029/2003GB002087, 2004.

Guo, L., Ping, C.-L., and Macdonald, R. W.: Mobilization pathways of organic carbon from permafrost to arctic rivers in a changing climate, Geophys. Res. Lett., 34, L13603, doi:10.1029/2007GL030689, 2007.

Gustafsson, Ö., van Dongen, B. E., Vonk, J. E., Dudarev, O. V., and Semiletov, I. P.: Widespread release of old carbon across the Siberian Arctic echoed by its large rivers, Biogeosciences, 8, 1737-1743, doi:10.5194/bg-8-1737-2011, 2011.

Hatten, J. A., Goñi, M. A., and Wheatcroft, R. A.: Chemical characteristics of particulate organic matter from a small, mountainous river system in the Oregon Coast Range, USA, Biogeochemistry, 107, 43-66, doi:10.1007/s10533-010-9529-z, 2012.

Hedges, J. and Mann, D.: The characterization of plant tissues by their lignin oxidation products, Geochim. Cosmochim. Ac., 43, 1803-1807, 1979.

Hedges, J. I. and Parker, P. L.: Land-derived organic matter in surface sediments from the Gulf of Mexico, Geochim. Cosmochim. Ac., 40, 1019-1029, doi:10.1016/0016-7037(76)90044-2, 1976.

Hedges, J. I. and Weliky, K.: Diagenesis of conifer needles in a coastal marine environment, Geochim. Cosmochim. Ac., 53, 2659-2673, doi:10.1016/0016-7037(89)90137-3, 1989.

Hedges, J., Ertel, J., and Leopold, E.: Lignin geochemistry of a Late Quaternary sediment core from Lake Washington, Geochim. Cosmochim. Ac., 46, 1869-1877, 1982.

Hedges, J., Clark, W., Quay, P., Richey, J., Devol, A., and Santos, U.: Compositions and fluxes of particulate organic material in the Amazon River, Limnol. Oceanogr., 31, 717-738, 1986.

Hedges, J., Blanchette, R., Weliky, K., and Devol, A.: Effects of fungal degradation on the $\mathrm{CuO}$ oxidation products of lignin: a controlled laboratory study, Geochim. Cosmochim. Ac., 52, 27172726, 1988.

Hernes, P. and Benner, R.: Transport and diagenesis of dissolved and particulate terrigenous organic matter in the North Pacific Ocean, Deep-Sea Res. Pt. I, 49, 2119-2132, 2002.

Hernes, P., Robinson, A., and Aufdenkampe, A.: Fractionation of lignin during leaching and sorption and implications for organic matter "freshness," Geophys. Res. Lett., 34, L17401, doi:10.1029/2007GL031017, 2007.

Herzschuh, U., Bolshiyanov, D., Pestrjakova, L., Boersma, M., Abramova, K., Zubrzycki, S., Biskaborn, B., Klemm, J., and Vakhrameeva, P.: Ecological state of permafrost lakes and their $\mathrm{c}$ atchment along an North-South transect in northcentral Yakutia: past and present, in: Russian-German Cooperation SYSTEM
LAPTEV SEA: The Expedition Lena 2009, edited by: Boike, J., Abramova, K., Bolshiyanov, D., Grigoriev, M., Herzschuh, U., Kattner, G., Knoblauch, C., Kutzbach, L., Mollenhauer, G., and Schneider W., Reports on Polar and Marine Research, 600, 22 24, 2009.

Holmes, R., McClelland, J., Peterson, B., Shiklomanov, I., Shiklomanov, A., Zhulidov, A., Gordeev, V., and Bobrovitskaya, N.: A circumpolar perspective on fluvial sediment flux to the Arctic Ocean, Global Biogeochem. Cy., 16, 1098, doi:10.1029/2001GB001849, 2002.

Holmes, R., McClelland, J., Peterson, B., Tank, S., Bulygina, E., Eglinton, T., Gordeev, V., Gurtovaya, T., Raymond, P., Repeta, D., Staples, R., Striegl, R., Zhulidov, A., and Zimov, S.: Seasonal and Annual Fluxes of Nutrients and Organic Matter from Large Rivers to the Arctic Ocean and Surrounding Seas, Estuar. Coast., 35, 369-382, doi:10.1007/s12237-011-9386-6, 2012.

Hu, F. S., Hedges, J. I., Gordon, E. S., and Brubaker, L. B.: Lignin biomarkers and pollen in postglacial sediments of an Alaskan lake, Geochim. Cosmochim. Ac., 63, 1421-1430, 1999.

IPCC: Climate change 2013, The physical science basis: Working group I contribution to the fifth assessment report of the IPCC, edited by: Stocker, T. F., Qin, D., Plattner, G.-K., Tignor, M. M. B., Allen, S. K., Boschung, J., Nauels, A., Xia, Y., Bex, V., and Midgley, P. M., IPCC, 5, 1525 pp., Cambridge University Press, Cambridge, UK and New York, USA, 2013.

Ivanov, V. V. and Piskun, A. A.: Distribution of river water and suspended sediment loads in the deltas of rivers in the basins of the Laptev and East-Siberian Seas, in: Land-ocean system in the Siberian Arctic. Dynamics and history, edited by: Kassens, H., Bauch, H. A., Dmitrenko, I. A., Eicken, H., Hubberten, H. W., Melles, M, Thiede, J., and Timokhov, L. A., Springer, Berlin, Germany, 239-250, 1999.

Karlsson, E. S., Charkin, A., Dudarev, O., Semiletov, I., Vonk, J. E., Sánchez-García, L., Andersson, A., and Gustafsson, Ö.: Carbon isotopes and lipid biomarker investigation of sources, transport and degradation of terrestrial organic matter in the BuorKhaya Bay, S E Laptev Sea, Biogeosciences, 8, 1865-1879, doi:10.5194/bg-8-1865-2011, 2011.

Klemm, J. and Zubrzycki, S.: Investigation on soil and vegetation units along a North-South transect in Northeast Siberia \& central part of Lena River Delta, Jakutia, in: Russian-German cooperation SYSTEM LAPTEV SEA, The expedition Lena 2009, vol. 600, edited by: Boike, J., Abramova, K., Bolshiyanov, D. Y., Grigoriev, M. N., Herzschuh, U., Kattner, G., Knoblauch, C., Kutzbach, L., Mollenhauer, G., and Schneider, W., Reports on Polar and Marine Research, 28-29, 2009.

Kutzbach, L., Wagner, D., and Pfeiffer, E.: Effect of microrelief and vegetation on methane emission from wet polygonal tundra, Lena Delta, Northern Siberia, Biogeochemistry, 69, 341362, 2004.

Kuzyk, Z., Goñi, M., Stern, G., and Macdonald, R.: Sources, pathways and sinks of particulate organic matter in Hudson Bay: Evidence from lignin distributions, Mar. Chem., 112, 215-229, doi:10.1016/j.marchem.2008.08.001, 2008.

Lisitsyn, A. P.: The marginal filter of the ocean, Oceanology of the Russian Academy of Sciences, 34, 671-682, 1995.

Lobbes, J., Fitznar, H., and Kattner, G.: Biogeochemical characteristics of dissolved and particulate organic matter in Russian 
rivers entering the Arctic Ocean, Geochim. Cosmochim. Ac., 64, 2973-2983, 2000.

Löfberg, J.: YALMIP: A toolbox for modeling and optimization in MATLAB, IEEE International Symposium on Computer Aided Control System Design, 284-289, doi:10.1109/CACSD.2004.1393890, 2004.

McClelland, J. W., Holmes, R., Dunton, K., and Macdonald, R.: The Arctic Ocean estuary, Estuar. Coast., 35, 353-368, 2012.

Moreira-Turcq, P., Bonnet, M.-P., Amorim, M., Bernardes, M., Lagane, C., Maurice, L., Perez, M., and Seyler, P.: Seasonal variability in concentration, composition, age, and fluxes of particulate organic carbon exchanged between the floodplain and Amazon River, Global Biogeochem. Cy., 27, 119-130, doi:10.1002/gbc.20022, 2013.

Morgenstern, A., Grosse, G., and Schirrmeister, L.: Genetic, morphological, and statistical characterization of lakes in the permafrost-dominated Lena Delta, in: Proceedings of the Ninth International Conference on Permafrost, 1239-1244, 2008.

Mueller-Lupp, T., Bauch, H., Erlenkeuser, H., Hefter, J., Kassens, H., and Thiede, J.: Changes in the deposition of terrestrial organic matter on the Laptev Sea shelf during the Holocene: evidence from stable carbon isotopes, Int. J. Earth Sci., 89, 563-568, doi:10.1007/s005310000128, 2000.

Onstad, G., Canfield, D., Quay, P., and Hedges, J.: Sources of particulate organic matter in rivers from the continental USA: Lignin phenol and stable carbon isotope compositions, Geochim. Cosmochim. Ac., 64, 3539-3546, 2000.

Opsahl, S. and Benner, R.: Early Diagenesis of Vascular PlantTissues - Lignin and Cutin Decomposition and Biogeochemical Implications, Geochim. Cosmochim. Ac., 59, 4889-4904, 1995.

Opsahl, S., Benner, R., and Amon, R. M. W.: Major flux of terrigenous dissolved organic matter through the Arctic Ocean, Limnol. Oceanogr., 44, 2017-2023, 1999.

Peterson, B., Holmes, R., McClelland, J., Vörösmarty, C., Lammers, R., Shiklomanov, A., Shiklomanov, I., and Rahmstorf, S.: Increasing river discharge to the Arctic Ocean, Science, 298, 2171-2173, 2002.

Prahl, F., Ertel, J., Goñi, M., Sparrow, M., and Eversmeyer, B.: Terrestrial organic carbon contributions to sediments on the Washington margin, Geochim. Cosmochim. Ac., 58, 3035-3048, 1994.

Rachold, V.: Major, trace and rare earth element geochemistry of suspended particulate material of East Siberian rivers draining to the Arctic Ocean, in: Land-ocean system in the Siberian Arctic. Dynamics and history, edited by: Kassens, H., Bauch, H. A., Dmitrenko, I. A., Eicken, H., Hubberten, H. W., Melles, M., Thiede, J., and Timokhov, L. A., Springer, Berlin, Germany, 199222, 1999.

Rachold, V. and Hubberten, H. W.: Carbon isotope composition of particulate organic material in East Siberian rivers, in: Landocean system in the Siberian Arctic. Dynamics and history, edited by: Kassens, H., Bauch, H. A., Dmitrenko, I. A., Eicken, H., Hubberten, H. W., Melles, M., Thiede, J., and Timokhov, L. A., Springer, Berlin, Germany, 223-238, 1999.

Rachold, V., Eicken, H., Gordeev, V. V., Grigoriev, M. N., Hubberten, H. W., Lisitzin, A. P., Shevchenko, V. P., and Schirrmeister, L.: Modern terrigenous organic carbon input to the Arctic Ocean, in: The organic carbon cycle in the Arctic Ocean, edited by: Stein R. and Macdonald, R. W., Springer, Berlin, Germany, 33-55, 2004

Raymond, P. A., McClelland, J. W., Holmes, R. M., Zhulidov, A. V., Mull, K., Peterson, B. J., Striegl, R. G., Aiken, G. R., and Gurtovaya, T. Y.: Flux and age of dissolved organic carbon exported to the Arctic Ocean: A carbon isotope study of the five largest arctic rivers, Global Biochem. Cy., 21, GB4011, doi:10.1029/2007GB002934, 2007.

Rice, D. L. and Hanson, R. B.: A kinetic model for detritus nitrogen: Role of the associated bacteria in nitrogen accumulation, B. Mar. Sci., 35, 326-340, 1984.

Sachs, T., Giebels, M., Boike, J., and Kutzbach, L.: Environmental controls on $\mathrm{CH} 4$ emission from polygonal tundra on the microsite scale in the Lena river delta, Siberia, Glob. Change Biol., 16, 3096-3110, 2010.

Sanchéz-García, L., Alling, V., Pugach, S., Vonk, J., van Dongen, B., Humborg, C., Dudarev, O., Semiletov, I., and Gustafsson, Ö.: Inventories and behavior of particulate organic carbon in the Laptev and East Siberian seas, Global Biogeochem. Cy., 25, GB2007, doi:10.1029/2010GB003862, 2011.

Sanders, T.: Charakterisierung Ammoniak oxidierender Mikroorganismen in Böden kalter und gemäßigter Klimate und ihre Bedeutung für den globalen Stickstoffkreislauf, Ph.D, University of Hamburg, 157 pp., 2011.

Schirrmeister, L., Kunitsky, V., Grosse, G., Wetterich, S., Meyer, H., Schwamborn, G., Babiy, O., Derevyagin, A., and Siegert, C.: Sedimentary characteristics and origin of the Late Pleistocene Ice Complex on north-east Siberian Arctic coastal lowlands and islands - A review, Quatern. Int., 241, 3-25, doi:10.1016/j.quaint.2010.04.004, 2011.

Schuur, E., Bockheim, J., Canadell, J., Euskirchen, E., Field, C., Goryachkin, S., Hagemann, S., Kuhry, P., Lafleur, P., Lee, H., Mazhitova, G., Nelson, F., Rinke, A., Romanovsky, V., Shiklomanov, N., Tarnocai, C., Venevsky, S., Vogel, J., and Zimov, S.: Vulnerability of permafrost carbon to climate change: Implications for the global carbon cycle, Bioscience, 58, 701-714, doi:10.1641/B580807, 2008.

Schwamborn, G., Rachold, V., and Grigoriev, M.: Late Quaternary sedimentation history of the Lena Delta, Quatern. Int., 89, 119134, 2002.

Semiletov, I. P., Pipko, I. I., Shakhova, N. E., Dudarev, O. V., Pugach, S. P., Charkin, A. N., McRoy, C. P., Kosmach, D., and Gustafsson, Ö.: Carbon transport by the Lena River from its headwaters to the Arctic Ocean, with emphasis on fluvial input of terrestrial particulate organic carbon vs. carbon transport by coastal erosion, Biogeosciences, 8, 2407-2426, doi:10.5194/bg8-2407-2011, 2011.

Stein, R. and Fahl, K.: The Laptev Sea: Distribution, sources, variability and burial of organic carbon, in The organic carbon cycle in the Arctic Ocean, edited by: Stein R. and Macdonald, R. W., Springer, Berlin, Germany, 213-237, 2004.

Tarnocai, C., Canadell, J., Schuur, E., Kuhry, P., Mazhitova, G., and Zimov, S.: Soil organic carbon pools in the northern circumpolar permafrost region, Globa Biochem. Cy., 23, GB2023, doi:10.1029/2008GB003327, 2009.

Tesi, T., Miserocchi, S., Goñi, M. A., and Langone, L.: Source, transport and fate of terrestrial organic carbon on the western Mediterranean Sea, Gulf of Lions, France, Mar. Chem., 105, 101-117, doi:10.1016/j.marchem.2007.01.005, 2007. 
Tesi, T., Miserocchi, S., Goñi, M. A., Turchetto, M., Langone, L., De Lazzari, A., Albertazzi, S., and Correggiari, A.: Influence of distributary channels on sediment and organic matter supply in event-dominated coastal margins: the Po prodelta as a study case, Biogeosciences, 8, 365-385, doi:10.5194/bg-8-365-2011, 2011.

Tesi, T., Semiletov, I., Hugelius, G., Dudarev, O., Kuhry, P., and Gustafsson, Ö.: Composition and fate of terrigenous organic matter along the Arctic land-ocean continuum in EastSiberia: Insights from biomarkers and carbon isotopes, Geochim. Cosmochim. Ac., 133, 235-256, doi:10.1016/j.gca.2014.02.045, 2014.

Tsutsuki, K. and Kondo, R.: Lignin-derived phenolic compounds in different types of peat profiles in Hokkaido, Japan, Soil Sci. Plant Nutr., 41, 515-527, doi:10.1080/00380768.1995.10419613, 1995.

Unger, D., Gaye-Haake, B., Neumann, K., Gebhardt, A., and Ittekkot, V.: Biogeochemistry of suspended and sedimentary material in the $\mathrm{Ob}$ and Yenisei rivers and Kara Sea: amino acids and amino sugars, Cont. Shelf Res., 25, 437-460, doi:10.1016/j.csr.2004.09.014, 2005.

Vonk, J. E., Sánchez-García, L., Semiletov, I., Dudarev, O., Eglinton, T., Andersson, A., and Gustafsson, Ö.: Molecular and radiocarbon constraints on sources and degradation of terrestrial organic carbon along the Kolyma paleoriver transect, East Siberian Sea, Biogeosciences, 7, 3153-3166, doi:10.5194/bg-73153-2010, 2010.

Vonk, J. E., Sanchéz-García, L., van Dongen, B. E., Alling, V., Kosmach, D., Charkin, A., Semiletov, I. P., Dudarev, O. V., Shakhova, N., Roos, P., Eglinton, T. I., Andersson, A., and Gustafsson, Ö.: Activation of old carbon by erosion of coastal and subsea permafrost in Arctic Siberia, Nature, 489, 137-140, doi:10.1038/nature11392, 2012.
Wetterich, S., Kuzmina, S., Andreev, A., Kienast, F., Meyer, H., Schirrmeister, L., Kuznetsova, T., and Sierralta, M.: Palaeoenvironmental dynamics inferred from late Quaternary permafrost deposits on Kurungnakh Island, Lena Delta, Northeast Siberia, Russia, Quaternary Sci. Rev., 27, 1523-1540, doi:10.1016/j.quascirev.2008.04.007, 2008.

Williams, C., Yavitt, J., Wieder, R., and Cleavitt, N.: Cupric oxide oxidation products of northern peat and peat-forming plants, Can. J. Bot., 76, 51-62, 1998.

Winterfeld, M. and Mollenhauer, G.: Characterization of particulate organic matter in the Lena River Delta and adjacent nearshore zone, NE Siberia - Part 2: Radiocarbon inventories, Biogeosciences Discuss., 11, 14413-14451, doi:10.5194/bgd11-14413-2014, 2014.

Yang, D., L, K. D., Hinzman, L. D., Zhang, X., Zhang, T., and Hengchun, Y.: Siberian Lena River hydrologic regime and recent change, J. Geophys. Res., 107, 4694, doi:10.1029/2002JD002542, 2002.

Zhang, T., Frauenfeld, O., Serreze, M., Etringer, A., Oelke, C., McCreight, J., Barry, R., Gilichinsky, D., Yang, D., Ye, H., Ling, F. and Chudinova, S.: Spatial and temporal variability in active layer thickness over the Russian Arctic drainage basin, J Geophys. Res., 110, D16101, doi:10.1029/2004JD005642, 2005.

Zocatelli, R., Moreira-Turcq, P., Bernardes, M., Turcq, B., Cordeiro, R. C., Gogo, S., Disnar, J. R., and Boussafir, M. Sedimentary evidence of soil organic matter input to the Curuai Amazonian floodplain, Org. Geochem., 63, 40-47, doi:10.1016/j.orggeochem.2013.08.004, 2013.

Zubrzycki, S., Kutzbach, L., and Pfeiffer, E.: Variability of Soil Organic Carbon Stocks of Different Permafrost-Affected Soils: Initial Results from a North-South Transect in Siberia, in: Tenth International Conference on Permafrost, 1-6, 2012. 